Prepared in cooperation with the American Bird Conservancy

\title{
Interior Least Tern Sandbar Nesting Habitat Measurements from Landsat Thematic Mapper Imagery
}

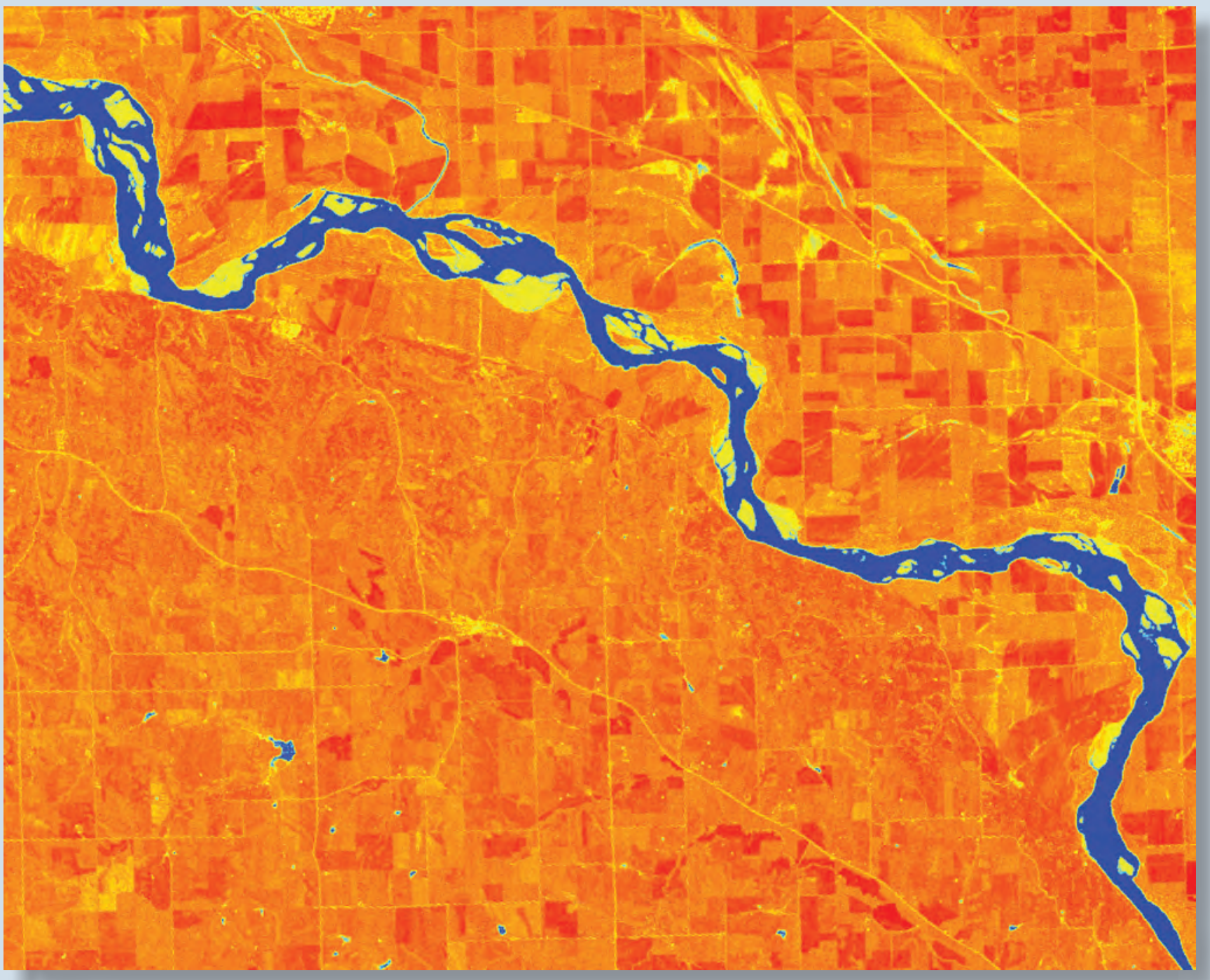

Data Series 1098

U.S. Department of the Interior

U.S. Geological Survey 
Cover. Landsat-derived modified normalized difference water index image showing Missouri River downstream from Gavins Point Dam, South Dakota. 


\section{Interior Least Tern Sandbar Nesting Habitat Measurements from Landsat Thematic Mapper Imagery}

By Edward A. Bulliner, Caroline M. Elliott, Robert B. Jacobson, and Casey Lott

Prepared in cooperation with the American Bird Conservancy

Data Series 1098 


\section{U.S. Department of the Interior \\ RYAN K. ZINKE, Secretary}

\section{U.S. Geological Survey James F. Reilly II, Director}

\section{U.S. Geological Survey, Reston, Virginia: 2018}

For more information on the USGS - the Federal source for science about the Earth, its natural and living resources, natural hazards, and the environment-visit https://www.usgs.gov or call 1-888-ASK-USGS.

For an overview of USGS information products, including maps, imagery, and publications, visit https://store.usgs.gov.

Any use of trade, firm, or product names is for descriptive purposes only and does not imply endorsement by the U.S. Government.

Although this information product, for the most part, is in the public domain, it also may contain copyrighted materials as noted in the text. Permission to reproduce copyrighted items must be secured from the copyright owner.

Suggested citation:

Bulliner, E.A., Elliott, C.M., Jacobson, R.B., and Lott, C., 2018, Interior Least Tern sandbar nesting habitat measurements from Landsat Thematic Mapper imagery: U.S. Geological Survey Data Series 1098, 32 p., https://doi. org/10.3133/ds1098.

ISSN 2327-638X (online) 


\section{Contents}

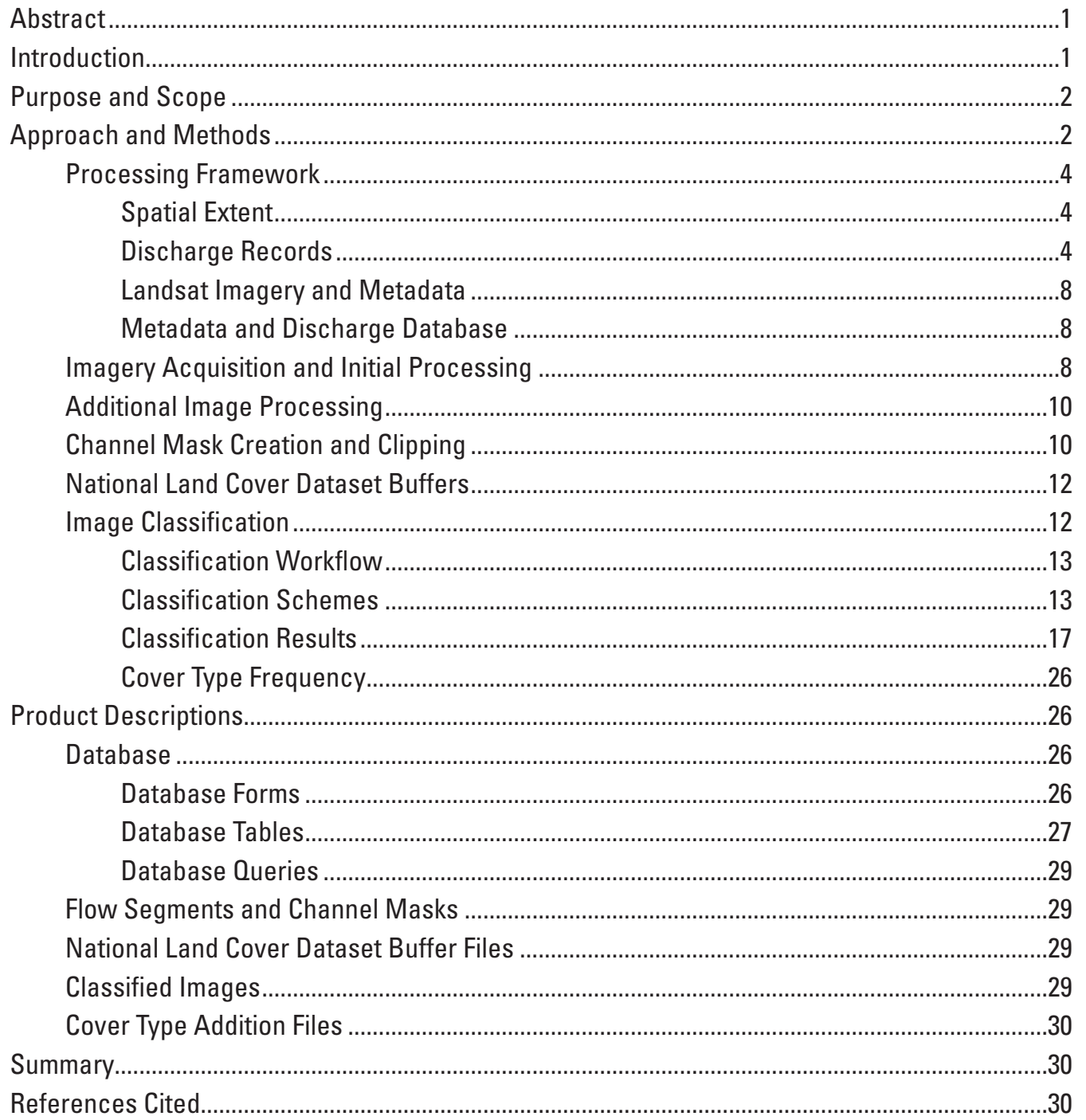




\section{Figures}

1. Map showing locations of flow segments included in database spatial extent and overlapping Landsat Worldwide Reference System path/row scene designations.........3

2. Screenshot showing database structure to link Landsat metadata with compiled discharge and stage records.

3. Diagram showing classification scheme A ruleset ......................................................14

4. Diagram showing classification scheme $B$ ruleset ..................................................15

5. Diagram showing classification scheme $\mathrm{C}$ ruleset...................................................15

6. Map showing a sample of classification data for flow segment Red 4, path/row 25037 .

7. National Agriculture Imagery Program imagery for flow segment Red 5 and visually based classification as compared to three Landsat-based classification schemes.

8. National Agriculture Imagery Program imagery for flow segment Missouri 6 and visually based classification as compared to three Landsat-based classification schemes

9. Map showing sample cover type addition files for the Red River flow segment 4, path/row 25037

\section{Tables}

1. Rivers identified to be included in Landsat metadata and discharge database.

2. Number of unique flow segments identified for rivers within the spatial extent of each dataset by river.

3. Segment numbers and type of record used to quantify river level for all flow segments in spatial extent of dataset

4. Average width of channel masks per river flow segment. Mask widths were quantified by merging all masks from any flow segment/path/row overlaps for each river flow segment.

5. Number of analyzed flow segment/path/row intersections for each classified flow segment.

6. Number of images meeting all quality criteria analyzed for each flow segment/path/row combination in which classification results were generated...........16

7. Classification legend for classification schemes $A, B$, and $C$

8. Sensitivity analysis comparing classification schemes $A, B$, and $C$ per flow segment.

9. Comparison of classification data between National Agricultural Imagery Program and Landsat-based classification schemes, Red River

10. Comparison of classification data between National Agricultural Imagery Program and Landsat-based classification schemes, Missouri River.....

11. Comparison of classification data between National Agricultural Imagery Program and Landsat-based classification schemes, Red River, for select individual classes

12. Comparison of classification data between National Agricultural Imagery Program and Landsat-based classification schemes, Missouri River, for select individual classes

13. Minimum discharge thresholds used to create sand and water addition files 


\section{Conversion Factors and Datum}

U.S. customary units to International System of Units

\begin{tabular}{lll}
\hline \multicolumn{1}{c}{ Multiply } & By & \multicolumn{1}{c}{ To obtain } \\
\hline foot $(\mathrm{ft})$ & Length & meter $(\mathrm{m})$ \\
mile (mi) & 0.3048 & kilometer $(\mathrm{km})$ \\
\hline & 1.609 & \\
\hline cubic foot per second $\left(\mathrm{ft}^{3} / \mathrm{s}\right)$ & Flow rate & cubic meter per second $\left(\mathrm{m}^{3} / \mathrm{s}\right)$ \\
\hline
\end{tabular}

\section{Supplemental Information}

Horizontal coordinate information is referenced to the World Geodetic System of 1984 (WGS 1984) because this is the coordinate system used by Landsat imagery.

To communicate effectively with managers, this report uses a mixture of U.S. customary units and International System of Units (SI) units of measure. Discharges are referenced in the customary units of cubic feet per second $\left(\mathrm{ft}^{3} / \mathrm{s}\right)$, whereas distances and areas are described in SI units to match Landsat measurement standards.

\section{Abbreviations}

$\begin{array}{ll}\text { CDR } & \text { Climate Data Record } \\ \text { EROS } & \text { Earth Resources Observation Systems } \\ \text { geotiff } & \text { georeferenced tagged image file format files } \\ \text { ILT } & \text { Interior Least Tern } \\ \text { MNDWI } & \text { Modified Normalized Difference Water Index } \\ \text { NAIP } & \text { National Agricultural Imagery Program } \\ \text { NDVI } & \text { Normalized Difference Vegetation Index } \\ \text { NHD } & \text { National Hydrography Dataset } \\ \text { NLCD } & \text { National Land Cover Dataset } \\ \text { TM } & \text { Thematic Mapper (Landsat 4-5 sensor) } \\ \text { USACE } & \text { U.S. Army Corps of Engineers } \\ \text { USGS } & \text { U.S. Geological Survey } \\ \text { UTM } & \text { Universal Transverse Mercator } \\ \text { WRS } & \text { Worldwide Reference System }\end{array}$





\title{
Interior Least Tern Sandbar Habitat Nesting Measurements from Landsat Thematic Mapper Imagery
}

\author{
By Edward A. Bulliner, Caroline M. Elliott, Robert B. Jacobson, and Casey Lott ${ }^{1}$
}

\section{Abstract}

Sandbars of large sand-bedded rivers of the central United States serve important ecological functions to many species, including the endangered Interior Least Tern (Sternula antillarum, ILT). The ILT is a colonial bird that feeds on fish and nests primarily on riverine sandbars during its annual breeding season of around May through July, depending on region. During this time, ILTs require bare sand of sufficient elevation so as not to be inundated between nest initiation and fledging of hatchlings. Partly because of decreases in available sandbar habitat from river channelization and impoundment, ILTs were listed as endangered in 1985.

Sandbars used by ILTs in central United States rivers are highly dynamic and undergo substantive changes across a wide range of temporal and spatial scales. River hydrology is the primary driver of sandbar morphodynamics in these systems. Better characterization of sandbar area with time, accounting for varying flow regimes, allows for a better understanding of landscape-scale ecology for sandbar-dependent species such as the ILT. This work uses remote-sensing techniques to quantify sandbar area that may be used by ILTs at the landscape scale and how it has changed with time. The assessment of landscape-scale trends in sandbar area with time requires datasets with high temporal resolution and long record periods covering large geographic areas. Evaluation of remotely sensed datasets requires consideration of river stage fluctuations. To make this assessment, we developed land-cover classification datasets within active channel masks using all available images from the Landsat Thematic Mapper series of satellites meeting cloud-free (40 percent or less) and ice-free criteria. Landsat imagery was selected because of its long record period, spatial coverage, and regular reimaging cycle, making it well suited to monitor ILT sandbar habitat with time. We also attributed each scene with discharge or stage using a new database integrating U.S. Geological Survey and U.S. Army Corps of Engineers river data with Landsat metadata. This report documents development of these riverine classification datasets with a focus on applicability to the ILT. This framework may be used to continue monitoring the ILT sandbar nesting habitat or to evaluate other aquatic and terrestrial species whose life cycles are related to sandbars and channel complexity.

\section{Introduction}

Sandbars and associated river features provide habitat conditions used by several species. Channel habitat diversity is increased by sandbars and associated low-velocity flows (Johnson and Jennings, 1998). One species associated with sandbars is the Interior Least Tern (Sternula antillarum, ILT), which was originally listed as endangered in 1985 by the U.S. Fish and Wildlife Service (Engel, 1985). Threats to the species have been identified as actual and functional losses of riverine sandbar habitat because of the channelization and impoundment of large river systems (U.S. Fish and Wildlife Service, 1990).

The ILTs are colonial birds that nest on barren, sandy substrates of rivers (Thompson and others, 1997). The ILTs are distinguished from Coastal Least Terns geographically; Least Terns that nest on or along rivers of the Central Great Plains, the lower Mississippi Valley, and along Texas rivers greater than 80 kilometers $(\mathrm{km})$ from the Gulf of Mexico coast are considered part of the Interior population (Engel, 1985). This part of the range is used only during the spring and summer reproductive and nesting season (around May-July) (U.S. Fish and Wildlife Service, 2013). The ILT population consists of numerous regional subpopulations geographically separated by reservoirs and channelized reaches unsuitable for nesting (U.S. Fish and Wildlife Service, 2005; Lott, 2006). A range-wide survey of the ILT population identified at least 480 nesting colonies spread across 18 States (Lott, 2006). The ILTs require sandbars with specific characteristics for successful nesting, including areas with sufficient elevation to avoid inundation during egg laying and incubation, sparse ground vegetation, and sufficient distance from trees to avoid large predatory birds (Lott and Wiley, 2012).

Sandbars of sand-bedded rivers in the central United States used by ILTs for nesting are highly dynamic. Sandbar area for a given river location varies with time because of erosional and depositional processes; sandbar dynamics related to these processes may be considered morphodynamics (Jacobson, 2013). Rates at which these processes happen vary by discharge (Alexander and others, 2013). Larger flows also have the effect of mobilizing large amounts of bed and bank material and forming new sandbars (Rubin and others,

${ }^{1}$ American Bird Conservancy. 
1990). Additionally, vegetation succession changes the surface coverage of sandbars with time at different rates depending on multiple factors including inundation frequency, which is related to sandbar elevation (Dixon and others, 2002). Total sandbar area and sandbar area functional for ILT nesting are thought to have decreased during the past century because of river impoundment and channelization (Engel, 1985; U.S. Fish and Wildlife Service, 1990).

Exposed sandbar area also varies dynamically with inundation or exposure. In the absence of erosion and deposition, or with amounts of erosion and deposition that are small enough that they can be neglected, dynamic changes in sandbar area can be considered hydrodynamic (Jacobson, 2013). Hydrodynamic variation typically happens in seasonal to annual periods between hydrologic events that transport sediment and resculpt sandbars. Historical variation of sandbar area results from morphodynamic and hydrodynamic processes, and distinguishing between the two is a substantial challenge.

The ILT has exhibited metapopulation dynamics. Dispersion of ILTs to areas with anthropogenic habitats that were not documented as part of the bird's historical range indicates possible connectivity between various ILT subpopulations (Lott and others, 2013). Given these dynamics, poor habitat conditions in 1 year for a given river may not have a large effect on the species population as a whole. Understanding the effect of local alterations of habitat on the species population, therefore, requires an understanding of habitat at the landscape scale - that is, a scale that encompasses the large rivers of the Great Plains (fig. 1). As part of its most recent 5-year review, the U.S. Fish and Wildlife Service (U.S. Fish and Wildlife Service, 2013) recommended the development of a habitat-driven metapopulation model. Such a model would aim to incorporate ILT dispersal behavior with different models of habitat dynamics to predict long-term (greater than 3-year) trends in ILT population. This report documents an initial effort to quantify sandbar area at the landscape scale used by the ILT and may be used in the future to inform the habitat dynamics part of a metapopulation model.

Full characterization of sandbars used by the ILT at the landscape scale requires a large dataset with sufficient temporal and spatial coverage to fully characterize the ephemeral nature of sandbars across different river systems. The Landsat series of Earth-observing satellites, a joint venture between the U.S. Geological Survey (USGS) and the National Aeronautics and Space Administration, maps the entire surface of Earth at regular intervals. Landsat 4 and Landsat 5 platforms had a Landsat Thematic Mapper (TM) sensor onboard and together produced a record period from 1982 to 2011 (Irish, 2000). With a regular reimaging cycle and long record period, Landsat TM imagery has the potential to provide a unique, valuable source of information on sandbars in rivers of the central United States. The 30-meter $(\mathrm{m})$ resolution of the imagery, however, limits practical application to large rivers with bankfull widths of about $100 \mathrm{~m}$ and greater.

\section{Purpose and Scope}

The purpose of this report is to document methods used to create riverine land-cover classification data (simply referred to as "classification data") for quantifying sandbar area potentially used by the ILT across large rivers of the central United States. The database and classification products presented are intended to provide a systematic calculation of sandbar area across all usable images in the Landsat $\mathrm{TM}$ archive while accounting for varying river stage (data are hosted on ScienceBase as a data release at https://doi. org/10.5066/F7CV4GNG; Bulliner, 2018). We present classified land-cover datasets for multiple flow segments from eight rivers, along with a database containing Landsat metadata and discharge records for all relevant Landsat images. The database encompasses all imagery for the eight classified rivers along with five additional rivers less commonly used by the ILT and not investigated as part of this dataset. These five rivers consist of a very small fraction of the overall ILT population habitat and were deemed less important for this analysis; however, they were included in the database as a framework for future analysis if they should later be deemed important. This dataset was compiled using a combination of Landsat Climate Data Record (CDR) surface reflectance data products developed and processed by the USGS Earth Resources Observation Systems (EROS) Data Center (U.S. Geological Survey, 2014b), discharge data from the USGS streamgaging program (U.S. Geological Survey, 2016), and dam-release and river-stage records from the U.S. Army Corps of Engineers (USACE) (data available from various USACE offices, unpub. data). The intent of this dataset is to provide a historical summary of sandbars visible from the Landsat TM satellites on large rivers used by the ILT given all available images in the Landsat TM record period. Additionally, this dataset provides an analysis framework amenable for ongoing monitoring of sandbars that can be used by the ILT as nesting habitat.

\section{Approach and Methods}

The database and classification data integrate Landsat TM imagery with river-discharge records to present a historical summary of sandbar area in large rivers of the central United States used by the ILT. The following sections outline the steps taken to define the spatial extent of classification and discharge data and how remote-sensing data and discharge data were acquired to cover this domain. Next, we describe methods used to integrate the two data sources, followed by the image classification techniques used to identify sandbar features within the Landsat TM imagery. Lastly, we present methods used to create summary datasets identifying areas of persistent sand accumulation and inundation. The described database and associated classification data accompany this report in a USGS data release (Bulliner, 2018). 


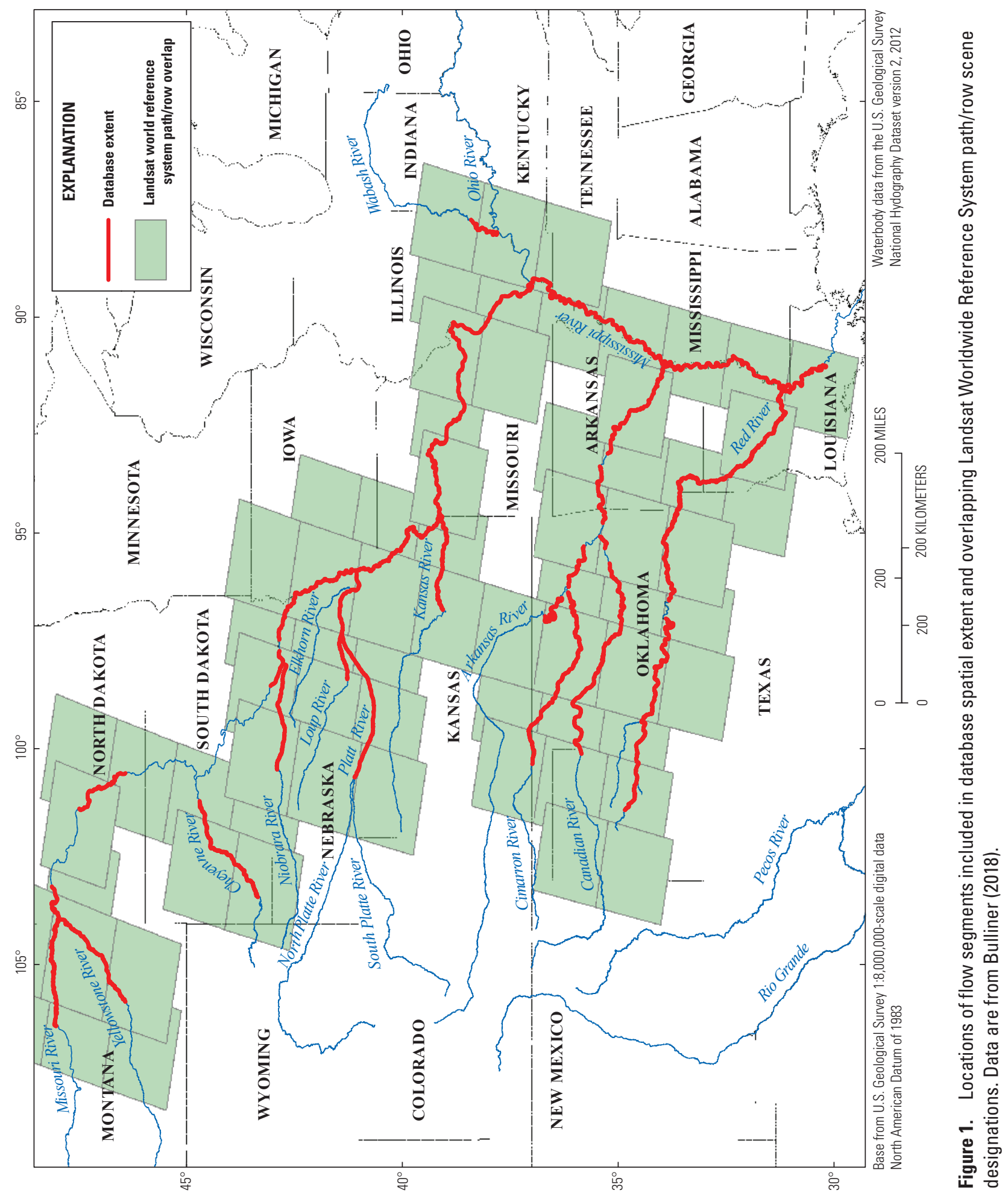




\section{Processing Framework}

Several data management and processing workflows were created to measure sandbar area visible in rivers of interest to the ILT. The first task was to define the rivers to be used for the spatial extent of the presented classification work. These rivers would need to be divided into areas of consistent discharge (segments) such that they could be attributed with a daily average discharge value. This step was important to provide hydrodynamic context for Landsat imagery of sandbars because the amount of sand visible in a remotely sensed image varies based on river stage. We opted to use daily average values for discharge because daily averages were commonly available for all images across the segments we identified. Segments of rivers with high within-day flow variation are common in the central United States (typically downstream from power-peaking hydroelectric dams), but reliable association of within-day discharges with individual Landsat scenes was not possible.

\section{Spatial Extent}

The first step in this work was to identify the spatial extent of the rivers to be processed. The spatial extent of the classification work was originally defined to include all central United States rivers that have had observed ILT use as defined by a compilation of rangewide surveys between 2002 and 2011 (Lott and others, 2013). A point-based ArcMap ${ }^{\circledR}$ shapefile that was created by Lott and others (2013) shows observed ILT colonies and denotes their location, such as inchannel sandbar versus out-of-channel sand pit. Any river with observed nesting on in-channel bars was included in this initial spatial domain; however, not all these rivers are included as part of the classification dataset for reasons described below. A list of the rivers included in this initial spatial extent definition, a two letter code used to refer to that river in the classification datasets, and an indication of if classification data for that river is included in this dataset are shown in table 1. Initially, these rivers were extracted as flowline shapefiles from the National Hydrography Dataset (NHD) version 2 (U.S. Geological Survey, 2013b). This dataset included the cumulative drainage area for each polyline feature, which would later be used as part of the segmentation process (McKay and others, 2012).

River-analysis boundaries were extended upstream past the last observed ILT colony by one flow segment (description follows). Each river was segmented into lengths between major tributaries, hereafter referred to as flow segments, through two steps. First, each river was inspected visually for locations of major tributaries using a combination of aerial photography and river base maps from Esri ArcGIS ${ }^{\circledR}$ online base maps (Esri, Inc.). A major tributary was defined subjectively as a tributary large enough to have a major effect on discharge levels downstream. The segmenting was made more objective by using NHD drainage area data to calculate junctions with tributaries where cumulative drainage area increased by greater than 2.5 percent. These junctions
Table 1. Rivers identified to be included in Landsat metadata and discharge database.

[Y refers to rivers where images were classified (yes), $\mathrm{N}$ refers to rivers where images were not classified (no)]

\begin{tabular}{lcc}
\hline \multicolumn{1}{c}{ River name } & River code & Classified \\
\hline Arkansas River & $\mathrm{AR}$ & $\mathrm{Y}$ \\
Canadian River & $\mathrm{CA}$ & $\mathrm{Y}$ \\
Cheyenne River & $\mathrm{CH}$ & $\mathrm{N}$ \\
Cimarron River & $\mathrm{CI}$ & $\mathrm{Y}$ \\
Kansas River & $\mathrm{KA}$ & $\mathrm{N}$ \\
Loup River & $\mathrm{LO}$ & $\mathrm{N}$ \\
Mississippi River & $\mathrm{MS}$ & $\mathrm{Y}$ \\
Missouri River & $\mathrm{MO}$ & $\mathrm{Y}$ \\
Niobrara River & $\mathrm{NI}$ & $\mathrm{Y}$ \\
Platte River & $\mathrm{PL}$ & $\mathrm{Y}$ \\
Red River & $\mathrm{RE}$ & $\mathrm{Y}$ \\
Wabash River & $\mathrm{WA}$ & $\mathrm{N}$ \\
Yellowstone River & $\mathrm{YE}$ & $\mathrm{N}$ \\
\hline
\end{tabular}

generally agreed with the created flow segment boundaries, except the upper Red River where several additional tributary boundaries were created. For rivers with reservoirs, flow segments terminated at the upstream extent of the reservoir, omitted the reservoir itself, and a new flow segment began downstream from the dam; reservoir reaches were not considered in this work. A final listing of the number of flow segments identified in each river is included in table 2 . The locations of identified flow segments, along with overlapping Landsat scene boundaries described below, are shown in figure 1. Flow segments are identified using their two letter river code and a numbering system starting at one for the most downstream flow segment and increasing moving upstream.

\section{Discharge Records}

The purpose of dividing each river in the spatial extent into flow segments was to create lengths where the daily average discharge could be assumed to have small spatial variation. Each flow segment would have one daily average discharge record applied for every day within the Landsat TM record period. In other words, there would be a one-toone relation between flow segment and streamgage record for a given day. The preferred method for attributing flow segments with discharge values was by matching to a USGS streamgage, where available.

For many flow segments, there was no available USGS streamgage. If flow segments were downstream from a dam, daily dam-release records were requested from the USACE. Average daily release rates were assumed to correspond to daily average discharge in the downstream flow segment. Additionally, some flow segments intensively managed by 
Table 2. Number of unique flow segments identified for rivers within the spatial extent of each dataset by river. Data are from Bulliner (2018).

\begin{tabular}{lc}
\hline \multicolumn{1}{c}{ River name } & Number of segments \\
\hline Arkansas River & 6 \\
Canadian River & 4 \\
Cheyenne River & 4 \\
Cimarron River & 5 \\
Kansas River & 4 \\
Loup River & 3 \\
Missouri River & 12 \\
Mississippi River & 7 \\
Niobrara River & 4 \\
Platte River & 3 \\
Red River & 15 \\
Wabash River & 1 \\
Yellowstone River & 2 \\
\hline
\end{tabular}

USACE for navigation purposes (the Red River navigation system and all the Mississippi except for the most upstream flow segment) do not have USGS streamgages but do have USACE stage measurement records. For these flow segments, stage records were acquired instead of discharge records. Compiled USACE dam and stage records included data from six USACE districts: Kansas City, Omaha, Memphis, Vicksburg, Little Rock, and Tulsa.

For flow segments without an overlapping USGS streamgage and no USACE data, discharge data were synthesized by joining some combination of upstream or downstream streamgages and adding or subtracting discharge from gaged tributaries, depending on their location. For example, if there was no streamgage for a flow segment downstream from a tributary but the upstream flow segment and tributary had USGS streamgages, streamgage records from the upstream flow segment and tributary were added together to calculate discharge in the downstream flow segment. This method to synthesize discharge records was needed only for upstream flow segments in smaller rivers. A summary of the type of data used to quantify discharge or river stage is included in table 3. Identification of the specific sources used for each flow segment is included in the database accompanying this data series.

Several basic modeling steps were completed to create a complete time series of daily average discharge records for 51 flow segments deemed most important to the ILT. For four flow segments, there were too many missing records across the time series from the initially identified streamgages to model missing discharge or stage values. Three of these flow segments, RE-10, RE-14, and MS-1, instead used the same records as an adjacent flow segment across the entirety of the time series. Ideally, these flow segments would have been merged with the flow segment whose records were used; however, because the database structure and mask files had already been generated when these gaps were identified, they were left as separate flow segments. A fourth flow segment, MO-8, had too many missing records for modeling processes described below. This flow segment is simply presented in the database with incomplete records.

Most remaining records amounted to periods of less than 1 year and were filled by interpolation or substitution from a nearby streamgage without discarding the rest of the discharge records for that flow segment. For records that were calculated from multiple streamgages, any records in which one or more of the component streamgages were missing data were discarded before filling in the dataset. Additionally, time series plots of daily flow/stage records for all 51 flow segments were inspected. From these, a small number of unrealistic values that were clearly recording errors were identified (for example, a single flow value of 152,000 cubic feet per second $\left[\mathrm{ft}^{3} / \mathrm{s}\right]$ during a week where all other flows were around $15,200 \mathrm{ft}^{3} / \mathrm{s}$, including flows at upstream and downstream streamgages). This editing amounted to 80 records.

For any missing record for which the gap in data was 7 or fewer consecutive days, values were interpolated using quadratic interpolation. For missing records for which the gap was greater than 7 consecutive days, values were linearly interpolated if upstream and downstream records showed minimal variation in flows during the missing period and if there was minimal variation in flows for that flow segment during the course of the year when records were missing. In total, using these two interpolation methods, 479 interpolated records were generated. If records were not amenable to interpolation using these steps, upstream and downstream streamgages were compared to the streamgages with missing data for the year in which records were missing. Oftentimes, flows were similar enough between the two streamgages to simply substitute data for an adjacent streamgage that year (for example, data from AR-1 is used for flow segment AR-2 in 1980). A total of 2,257 missing records were generated by substituting values from a nearby streamgage.

After interpolation and substitution, there were four combinations of flow segments and years with missing records. For a subset of days for CA-3 in 1983 and 1985, data from CA-2 were used. Flows between these two streamgages were nearly identical below $10,000 \mathrm{ft}^{3} / \mathrm{s}$. At flows below these values, records were copied from CA-2 to CA-3 (427 records); however, at higher flows, values at $\mathrm{CA}-3$ tended to be 50 percent lower than flows at $\mathrm{CA}-2$. Consequently, for these records, discharge values from CA-2 were cut in half to provide values for $\mathrm{CA}-3$ (30 records). The last two flow segment/year combinations with missing data were MS-5 in 1988 and 1998. Flows at this streamgage were typically half of those between MS-4 and MS-6. Consequently, average daily flows from these two streamgages in 1988 and 1998 were used as daily flows for MS-5 in these two years ( 728 records). In total, 4,001 new daily flow values across the 51 flow segments were generated. This amounted to 0.0067 percent of the flow records presented in the discharge database described below. 
Table 3. Segment numbers and type of record used to quantify river level (discharge or stage) for all flow segments in spatial extent of dataset. Data are from Bulliner (2018).

[USACE, U.S. Army Corps of Engineers; USGS, U.S. Geological Survey]

\begin{tabular}{|c|c|c|c|}
\hline River name & $\begin{array}{l}\text { Segment } \\
\text { identifier }\end{array}$ & Record type & Gage identifier \\
\hline Arkansas River & $\mathrm{AR}-1$ & USACE dam release & Wilbur D. Mills Dam \\
\hline Arkansas River & AR-2 & USACE dam release & Dardanelle Dam \\
\hline Arkansas River & AR-3 & USACE dam release & Robert S. Kerr Lock and Dam \\
\hline Arkansas River & $\mathrm{AR}-4$ & USGS streamgage & 07164500 \\
\hline Arkansas River & AR-5 & USGS streamgage & 07152500 \\
\hline Arkansas River & AR-6 & USACE dam release & Kaw Dam \\
\hline Canadian River & $\mathrm{CA}-1$ & USGS streamgage & 07245000 \\
\hline Canadian River & $\mathrm{CA}-2$ & USGS streamgage & 07231500 \\
\hline Canadian River & $\mathrm{CA}-3$ & USGS streamgage & 07229200 \\
\hline Canadian River & $\mathrm{CA}-4$ & USGS streamgage & 07228000 \\
\hline Cheyenne River & $\mathrm{CH}-1$ & USGS streamgage & 06438500 \\
\hline Cheyenne River & $\mathrm{CH}-2$ & Synthesized USGS streamgage & 06423500 and 06425500 \\
\hline Cheyenne River & $\mathrm{CH}-3$ & USGS streamgage & 06423500 \\
\hline Cheyenne River & $\mathrm{CH}-4$ & USGS streamgage & 06402600 \\
\hline Cimarron River & $\mathrm{CI}-1$ & USGS streamgage & 07160000 \\
\hline Cimarron River & $\mathrm{CI}-2$ & USGS streamgage & 07159100 \\
\hline Cimarron River & $\mathrm{CI}-3$ & USGS streamgage & 07158000 \\
\hline Cimarron River & $\mathrm{CI}-4$ & USGS streamgage & 07157950 \\
\hline Cimarron River & $\mathrm{CI}-5$ & Synthesized USGS streamgage & $07157950-07157500$ \\
\hline Kansas River & $\mathrm{KA}-1$ & USGS streamgage & 06892350 \\
\hline Kansas River & $\mathrm{KA}-2$ & USGS streamgage & 06891000 \\
\hline Kansas River & KA-3 & USGS streamgage & 06889000 \\
\hline Kansas River & $\mathrm{KA}-4$ & USGS streamgage & 06879100 \\
\hline Loup River & LO-1 & USGS streamgage & 06793000-06794000 \\
\hline Loup River & LO-2 & USGS streamgage & 06793000 \\
\hline Loup River & $\mathrm{LO}-3$ & Synthesized USGS streamgage & 06790500 and 06785000 \\
\hline Missouri River & MO-1 & USGS streamgage & 06934500 \\
\hline Missouri River & MO-10 & USGS streamgage & 06342500 \\
\hline Missouri River & MO-11 & Synthesized USGS streamgage & 06177000 and 06329500 \\
\hline Missouri River & MO-12 & USGS streamgage & 06177000 \\
\hline Missouri River & $\mathrm{MO}-2$ & USGS streamgage & 06909000 \\
\hline Missouri River & $\mathrm{MO}-3$ & USGS streamgage & 06818000 \\
\hline Missouri River & $\mathrm{MO}-4$ & USGS streamgage & 06610000 \\
\hline Missouri River & $\mathrm{MO}-5$ & USGS streamgage & 06486000 \\
\hline Missouri River & MO-6 & Synthesized USGS streamgage & Gavins Point Dam and 06478500 \\
\hline Missouri River & MO-7 & USACE dam release & Gavins Point Dam \\
\hline Missouri River & MO-8 & Synthesized USGS streamgage & 06466700 \\
\hline Missouri River & MO-9 & USACE dam release & Fort Randall Dam \\
\hline Mississippi River & MS-1 & USACE stage & Mississippi River at Natchez \\
\hline
\end{tabular}


Table 3. Segment numbers and type of record used to quantify river level (discharge or stage) for all flow segments in spatial extent of dataset. Data are from Bulliner (2018).-Continued

[USACE, U.S. Army Corps of Engineers; USGS, U.S. Geological Survey]

\begin{tabular}{|c|c|c|c|}
\hline River name & $\begin{array}{l}\text { Segment } \\
\text { identifier }\end{array}$ & Record type & Gage identifier \\
\hline Mississippi River & MS-2 & USACE stage & Mississippi River at Natchez \\
\hline Mississippi River & MS-3 & USACE stage & Mississippi River CE40F18A \\
\hline Mississippi River & MS-4 & USACE stage & Mississippi River MS133 \\
\hline Mississippi River & MS-5 & USACE stage & Mississippi River MS117 \\
\hline Mississippi River & MS-6 & USACE stage & Mississippi River CE40127 \\
\hline Mississippi River & MS-7 & USGS streamgage & 07010000 \\
\hline Niobrara River & NI-1 & USGS streamgage & 06465500 \\
\hline Niobrara River & NI-2 & Synthesized USGS streamgage & 06461500,06463500, and 06464500 \\
\hline Niobrara River & $\mathrm{NI}-3$ & Synthesized USGS streamgage & 06461500 and 06463500 \\
\hline Niobrara River & $\mathrm{NI}-4$ & USGS streamgage & 06461500 \\
\hline Platte River & $\mathrm{PL}-1$ & USGS streamgage & 06805500 \\
\hline Platte River & PL-2 & USGS streamgage & 06796000 \\
\hline Platte River & $\mathrm{PL}-3$ & USGS streamgage & 06770500 \\
\hline Red River & $\mathrm{RE}-1$ & USACE stage & Red River at Shreveport \\
\hline Red River & RE-10 & USGS streamgage & 07308500 \\
\hline Red River & RE-11 & Synthesized USGS streamgage & 07299540,07299670, and 07301110 \\
\hline Red River & RE-12 & Synthesized USGS streamgage & 07299540 and 07299670 \\
\hline Red River & RE-13 & USGS streamgage & 07299540 \\
\hline Red River & RE-14 & USGS streamgage & 07299540 \\
\hline Red River & RE-15 & USGS streamgage & 07297910 \\
\hline Red River & $\mathrm{RE}-2$ & Synthesized USGS streamgage & 07337000, Millwood Dam, and Wright Patman Dam \\
\hline Red River & $\mathrm{RE}-3$ & Synthesized USGS streamgage & 07337000 and Millwood Dam \\
\hline Red River & $\mathrm{RE}-4$ & USGS streamgage & 07337000 \\
\hline Red River & $\mathrm{RE}-5$ & Synthesized USGS streamgage & 07337000-Hugo Dam \\
\hline Red River & $\mathrm{RE}-6$ & USACE Dam Release & Dennison Dam \\
\hline Red River & $\mathrm{RE}-7$ & USGS streamgage & 07316000 \\
\hline Red River & RE-8 & Synthesized USGS streamgage & 07316000-07314900 \\
\hline Red River & RE-9 & USGS streamgage & 07308500 \\
\hline Wabash River & WA-1 & USGS streamgage & 03377500 \\
\hline Yellowstone River & YE-1 & USGS streamgage & 06329500 \\
\hline Yellowstone River & YE-2 & USGS streamgage & 06309000 \\
\hline
\end{tabular}




\section{Landsat Imagery and Metadata}

Landsat images are collected in alignment with paths and rows in a system referred to as the Worldwide Reference System, the second version of which (WRS-2) has been in use starting with Landsat 4 . Alignment with the WRS-2 produces images that are about $185 \mathrm{~km}$ wide (northwest to southeast) by $180 \mathrm{~km}$ tall (northeast to southwest). Repeat coverage for a path/row by an individual Landsat platform is possible once every 16 days. During periods of multiple Landsat satellite operation, satellite orbits have been spaced to provide 8-day repeat cycles. Targeted image centers are spaced $165 \mathrm{~km}$ apart to allow for nearly 10 percent image overlap and to ensure there are no gaps in surface coverage because of lateral drift of the satellite in its orbit (Irish, 2000); however, greater overlap happens between paths at higher latitudes. Combinations of WRS-2 paths and rows are referenced with a six digit number; the first three digits represent the path and the second three the row. Satellites travel from northeast to southwest during the daytime along a given path, and images are collected for every row of the WRS-2 along a given path. Adjacent row images along the same path generally are taken within 1 minute of each other, whereas images on adjacent paths are multiple days apart because of the orbital track of the satellite.

Landsat TM images consist of seven different bands with different electromagnetic wavelength ranges. For bands 1 through 5 and 7 , nominal sensor ground resolution is 30 meters $(\mathrm{m})$ by $30 \mathrm{~m}$ per pixel. Band 6 consists of a $120 \mathrm{~m}$ resolution thermal infrared sensor, although the data for this band also are resampled to $30 \mathrm{~m}$ spatial resolution before distribution. Imagery is distributed in a multiband format, and each band is individually extractable for analysis purposes.

Combinations of WRS -2 paths and rows that overlap flow segments within the spatial extent were identified through a geographic information system intersect operation using a shapefile of the WRS-2 and buffered NHD flowlines as input. For each overlapping path and row within the spatial extent of the dataset, Landsat metadata were extracted for all available Landsat 4 and 5 images from the USGS Landsat metadata website (U.S. Geological Survey, 2013a). These metadata included numerous descriptors of individual images, including hyperlinks to preview images, date and time of image capture, and an estimation of cloud cover for the image. These metadata were used as the basis for the creation of a database described below.

\section{Metadata and Discharge Database}

The spatial extents of selected rivers were used to identify needed Landsat metadata, which were integrated into a database with compiled discharge and stage records. The goal of this database was to keep track of different possible overlapping combinations of flow segments (unique to one discharge for a given day) and individual images. The overlaps between some part of a flow segment and an image for a given day would serve as the basic analysis unit presented in this data series. Additionally, scripts associated with this database incorporated tools to search for and identify individual images of interest, such as creating lists of images for a given flow segment that meet user-input discharge criteria.

All compiled discharge and stage records were included in the database. Though the Landsat TM record period only spans from 1982 to 2011, when available, discharge and stage records from outside this range of time were included in the database to allow for historical context of discharges during the Landsat record period. Additionally, all relevant Landsat metadata that were identified were included. These two datasets formed the main components of the database, and other tables and queries join and summarize these datasets in various ways.

The database was developed in Microsoft ${ }^{\circledR}$ Access (Microsoft, Redmond, Washington). The primary structures of the database are the "LandsatMetadata" tables, which store all compiled Landsat metadata, and the gage field, which stores daily average values of stage or discharge attributed by a streamgage identifier. This identifier was either a USGS streamgage number, abbreviation retained from the USACE data source (in USACE records, although these do not follow a standardized convention), or a formula representing a synthesized streamgage. Multiple many-to-many relations exist between Landsat images and streamgage values, so numerous intermediary tables were created to manage these relations in the database. The layout of these linking tables is shown in figure 2 . The database structure allows for numerous queries to be written and data to be extracted; for example, queries associated with the database are capable of listing all Landsat images for a given overlapping area between a flow segment and path/row that fall between user-input dates and meet userinput discharge (or stage) criteria.

The analysis framework of creating individual images clipped to an overlap between a flow segment and path/ row was important for data management and analysis. This approach allowed each analyzed image to be attributed with a single discharge value because each flow segment was attributed with only one discharge value for a given day. Hereafter, analysis will be described and presented in terms of flow segment/path/row overlaps. Each overlap consists of a static geographic area covered by imagery collected in one WRS-2 path/row. These overlaps are referenced by flow segment and then WRS-2 path/row, and the first digit of the path number is truncated because it is 0 for all overlapping paths. For example, MO6_29030 refers to flow segment number 6 of the Missouri River, and imagery is from path 029, row 030.

\section{Imagery Acquisition and Initial Processing}

The following sections describe the process of identifying and retrieving images that were deemed usable. Although the Landsat TM satellites collect images for a given geolocation at 16-day intervals, not all images are usable because of cloud cover, snow, or ice. Although ILTs only use sandbars during 


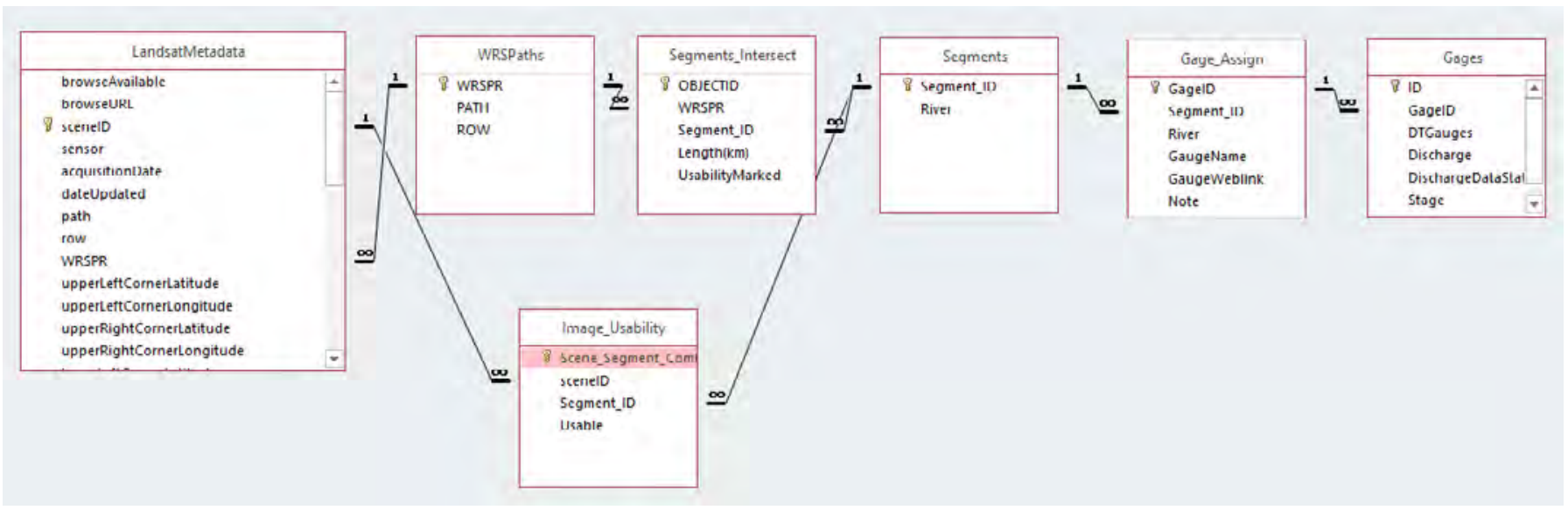

Figure 2. Database structure to link Landsat metadata with compiled discharge and stage records.

their nesting season of late spring through early summer, we analyzed all available imagery from the entire year because sandbar dynamics outside of the nesting season can still affect habitat availability during the nesting season.

Any images with 40 percent or greater estimated cloud cover in the Landsat metadata were discarded before any processing. Remaining images were visually inspected to determine if the cloud cover was where it could affect sandbar classification. This inspection was facilitated through a query in the database that provided a hyperlink to a lower resolution preview for a given image. A query in the metadata database was used to list unique combinations of flow segments and individual images. Each of these combinations was visually inspected to see if clouds obscured the flow segment of interest for that image. Any images in which clouds obscured a flow segment were discarded from analysis for that flow segment only; if an image contained multiple flow segments but only one flow segment was obscured, the image was still used for analysis on the remaining flow segments. Usability was tracked in a separate table in the database with an entry for each unique combination of Landsat image and flow segment. We note that the 40 percent cloud cover criterion was arbitrarily selected to speed the process of visually identifying usable imagery, and most images above this threshold tend to have too many clouds to be useful based on examining several flow segment/WRS-2 path/row intersections; there may be usable images for some areas that were excluded as part of this filtering process.

After all images were initially assessed for usability, a list of candidate images for each Landsat flow segment/path/ row combination was generated. Generally, each combination included between 150 and 200 usable images; longer flow segment/path/row intersections were more likely to be discarded because it was more likely a cloud would be obscuring at least part of the flow segment. Each combination of a flow segment and an image was treated as an individual unit for analysis, and a buffered area around each flow segment was later used to clip an associated Landsat image. This approach was used to account for the fact that most Landsat images (unclipped) contained multiple flow segments, but all flow segments were not necessarily usable for a particular image.

Initial work for this project was done using standard Landsat Level 1 top-of-atmosphere radiance products available through the USGS Earth Explorer web interface; however, while working on this project, the USGS made available a more highly processed version of Landsat TM data. As part of its effort to offer analysis-ready Landsat science products, the USGS is now offering Land Surface Reflectance Product images to which atmospheric corrections have been applied (U.S. Geological Survey, 2014b). As the name implies, pixel values in these images represent surface reflectance, which has been determined to produce more consistent, accurately calculated normalized reflectance ratios such as the normalized difference vegetation index (NDVI). A list of images for each path/row/flow segment combination was developed and submitted to the USGS EROS Science Processing Architecture (ESPA) interface (U.S. Geological Survey, 2014a). Requested images were processed in bulk through this service and downloaded to a local computer. The Landsat surface reflectance product also is now available through the USGS Earth Explorer file list web interface (https://earthexplorer.usgs.gov/ filelist) (U.S. Geological Survey, 2018).

Not all overlapping Landsat images initially identified as cloud free and usable were able to be downloaded and processed. "Level 1 Terrain Corrected," or L1T, products are used to generate the Landsat CDR. This level of processing provides the highest level of radiometric and geodetic accuracy available with Landsat data. For images to be processed to this level, data telemetered from the Landsat satellite at the time of collection must be incorporated into the processing algorithm. Because these data were not stored digitally initially, they are sometimes not recoverable for a given image (generally for images earlier in the time series), and that particular image is, therefore, not able to be processed as an L1T product. Images lacking level 1 corrections were identified during the request and download process and excluded from further analysis; the 
number of these images amounted to less than five per flow segment/path/row combination and was generally closer to one or two.

Originally, each image was provided in hierarchical data format. Images were first converted into georeferenced tagged image file format files (geotiff) and georeferenced to the local WGS 1984 Universal Transverse Mercator (UTM) zone using procedures from ArcGIS (Esri, Inc., Redlands, California). In total, 15,241 Landsat CDR surface-reflectance images were processed and downloaded to a local server for further calculations. The downloaded products amounted to 3.61 terabytes of disk space for images in their compressed formats.

\section{Additional Image Processing}

Channel masks were used to clip unnecessary data from single-band and calculated band-ratio images. For each image, two normalized band ratios were calculated. These included the Normalized Difference Vegetation Index (NDVI) (Rouse and others, 1973) and the Modified Normalized Difference Water Index (MNDWI) (Xu, 2006). In equation $1, N D V I$ is defined whereas in equation 2, MNDWI is defined.

$$
\begin{gathered}
N D V I=\frac{N I R-R}{N I R+R} \\
M N D W I=\frac{G-S W I R}{G+S W I R}
\end{gathered}
$$

where

$$
\begin{aligned}
& \text { NDVI } \text { is the Normalized Difference Vegetation } \\
& \text { Index; } \\
& N I R \quad \text { is the surface reflectance of electromagnetic } \\
& \text { radiation in near-infrared wavelengths; } \\
& R \quad \text { is the surface reflectance of electromagnetic } \\
& \text { radiation in red wavelengths; } \\
& \text { MNDWI } \quad \begin{array}{r}
\text { is the Modified Normalized Difference Water } \\
\text { Index; }
\end{array} \\
& \text { is the surface reflectance of electromagnetic } \\
& \text { radiation in green wavelengths; and } \\
& \text { is the surface reflectance of electromagnetic } \\
& \text { radiation in short-wave-infrared } \\
& \text { wavelengths. }
\end{aligned}
$$

For the Landsat TM satellites, green $(G)$ corresponds to band 2 , red $(R)$ to band 3 , near infrared (NIR) to band 4 , and short-wave-infrared (SWIR) to band 5; therefore, calculations of normalized band ratios for each image were calculated as shown in equations 3 and 4.

$$
N D V I=\frac{B 4-B 3}{B 4+B 3}
$$

$$
M N D W I=\frac{B 2-B 5}{B 2+B 5}
$$

where

$$
\begin{array}{cl}
\text { NDVI } & \text { is the Normalized Difference Vegetation } \\
& \text { Index; } \\
B 4 & \text { is Landsat TM band number 4; } \\
B 3 & \text { is Landsat TM band number 3; } \\
M N D W I & \text { is the Modified Normalized Difference Water } \\
& \text { Index; } \\
B 2 & \text { is Landsat TM band number 2; and } \\
B 5 & \text { is Landsat TM band number 5. }
\end{array}
$$

Images were processed using a combination of scripts from the Python ${ }^{\circledR}$ (Python Software Foundation) module ArcPy (Esri, Inc., Redlands, California) and IDL ${ }^{\circledR}$ version 8.2 (Exelis Visual Information Solutions, Boulder, Colorado).

Processed band ratios were saved for each downloaded image as geotiff files. Additionally, single-band images for bands 2 and 7 were saved because these would later be used as part of the classification workflow.

\section{Channel Mask Creation and Clipping}

Active-channel masks were created individually for all flow segment/path/row combinations. This step was important for quantification of sandbar area. Bare ground (specifically, not vegetation or water) was generally assumed to be a sandbar in the classification rulesets described; that is, if there was bare ground within the active channel of a river during the record period, it could be considered as a sandbar.

Masks were defined to include only the bankfull channel area for a river during the record period; however, because some rivers, particularly those in the southern plains, have migrated during that period, masks generally include some out-of-bank area for a given image even though that particular area may be considered in channel for an image at a different point in time. The size of these out-of-bank areas varies with the mobility of a given river during the Landsat TM record period. Initially, different masks for different parts of the time series were used to limit the amount of out-of-bank area included in each analyzed image; however, this approach proved challenging for data summary purposes and comparability of measurements. Therefore, all analyses presented use a single analysis mask for a given flow segment/path/row across the time series. Although masks created with this approach resulted in more out-of-bank area being included in the channel masks for some rivers, the resulting dataset is more consistent within each flow segment/path/row overlap and is more likely to capture the entire active channel for any given point within the Landsat TM record period.

Approximate bankfull discharges were estimated for each flow segment to create active channel masks. This discharge was used as a constant threshold across all overlapping paths/ rows. As a starting point, 5-year return interval discharges 
based on daily averages for each flow segment were calculated based on compiled discharge records. This discharge was used as a starting point, but ultimate determination of approximate bankfull discharge was made by looking at images from the compiled database. Generally, images within 10 percent of the 5 -year return interval were considered close enough to be used as a mask. The number of images suitable to be used as a mask for different flow segment/path/row combinations was somewhat random because it depends on the timing and frequency of bankfull discharges relative to Landsat image frequency, and if images coincident with appropriate discharges were cloud free. Typically, at least two to three bankfull images were selected for a given flow segment/path/row combination, although images corresponding to bankfull flows for flashier unregulated river systems in the southern plains were more difficult to identify. These rivers were the Upper Red River, Canadian River, and Cimarron River (fig. 1).

Pixels with an MNDWI value greater than 0 were extracted from identified images for each flow segment/path/ row and vectorized into shapefiles. Shapefiles from each image were merged together, dissolved, and trimmed to the upstream extent, the downstream extent, or both extents of the flow segment for a given flow segment/path/row overlap. Holes in the masks (gaps between migrating parts of the river, for example) were filled if they constituted less than 5 percent of the total mask area. Once a mask was created with this technique, a higher resolution aerial photograph base map in ArcGIS (Esri, Inc.) was used to identify any areas potentially missing from the mask (generally, only for the upstream flow segments of smaller rivers) because Landsat imagery at high flows across the record period was insufficient. Missing areas to the masks were edited in manually. Generated mask shapefiles were used to clip and mask calculated normalized band ratios and single band imagery per each flow segment/path/row overlap.

It should be noted that many of the rivers analyzed contain flow segments that are only several pixels wide given the $30 \mathrm{~m}$ spatial resolution of the Landsat TM sensor. This limited width applied to some of the uppermost flow segments of analyzed rivers (notably, the Red, Cimarron, Canadian, and Niobrara Rivers [fig. 1]). As the width of channel decreases, the utility of spatially coarse Landsat pixels to identify in-channel sandbars diminishes. In particular for the southern plains rivers, however, many flow segments with lower wetted-channel widths also are associated with large amounts of channel mobility during the Landsat 4-5 record period, along with large point-bar systems, which are used by the ILT for nesting. We, therefore, present the widths of the active-channel masks developed from Landsat imagery as a metric for assessing the utility of the $30 \mathrm{~m}$ spatial resolution of Landsat in quantifying changes to sandbar habitat.

To quantify average widths of channel masks and the variation thereof, we used Rivwidth (Pavelsky and Smith, 2008). For each flow segment, we merged all path/row overlaps into a single, continuous mask. We then processed each mask as a $30 \mathrm{~m}$ resolution raster using Rivwidth, which provides an estimate of channel width and number of channels (generally one channel for our data given the methods used to generate the masks) at a spatial interval along the channel centerline equivalent to the spatial resolution of the input raster. Rivwidth provides an estimate of channel width and number of channels every $30 \mathrm{~m}$ when the centerline traverses pixels directly adjacent and $42.4 \mathrm{~m}$ when the centerline traverses diagonal pixels for our dataset. The flow segment with the lowest mean mask width was Canadian 3, at $48.3 \mathrm{~m}$. This flow segment is likely too narrow for results to be of great utility; however, most segments had mean widths of several hundred meters. A list of mean mask width and standard deviation of mask width is presented in table 4 .

Table 4. Average width of channel masks per river flow segment. Mask widths were quantified by merging all masks from any flow segment/path/row overlaps for each river flow segment. These merged masks were analyzed with Rivwidth (Pavelsky and Smith, 2008) to quantify average mask width and standard deviation of mask width per river flow segment. Data are from Bulliner (2018).

[--, not applicable]

\begin{tabular}{|c|c|c|c|}
\hline River name & $\begin{array}{c}\text { Flow } \\
\text { segment }\end{array}$ & $\begin{array}{c}\text { Mean mask } \\
\text { width } \\
\text { (meters) }\end{array}$ & $\begin{array}{c}\text { Mask width } \\
\text { standard deviation } \\
\text { (meters) }\end{array}$ \\
\hline Arkansas River & $\mathrm{AR}-1$ & 469.5 & 284.0 \\
\hline Arkansas River & $\mathrm{AR}-2$ & 422.8 & 321.6 \\
\hline Arkansas River & $\mathrm{AR}-3$ & 355.3 & 250.4 \\
\hline Arkansas River & $\mathrm{AR}-4$ & 174.5 & 73.2 \\
\hline Arkansas River & $\mathrm{AR}-5$ & 139.8 & 56.0 \\
\hline Arkansas River & $\mathrm{AR}-6$ & 239.2 & 89.7 \\
\hline Canadian River & $\mathrm{CA}-1$ & 415.6 & 267.8 \\
\hline Canadian River & $\mathrm{CA}-2$ & 649.8 & 573.4 \\
\hline Canadian River & $\mathrm{CA}-3$ & 48.3 & 51.2 \\
\hline Canadian River & $\mathrm{CA}-4$ & 95.0 & 41.7 \\
\hline Cimarron River & CI-1 & 107.1 & 64.7 \\
\hline Cimarron River & $\mathrm{CI}-2$ & 128.3 & 31.9 \\
\hline Cimarron River & $\mathrm{CI}-3$ & 183.6 & 59.1 \\
\hline Missouri River & MO-6 & 360.6 & 193.0 \\
\hline Missouri River & MO-7 & $1,053.8$ & 560.4 \\
\hline Missouri River & MO-9 & 349.0 & 224.0 \\
\hline Missouri River & MO-10 & 225.0 & 248.2 \\
\hline Mississippi River & MS-1 & 950.5 & 341.5 \\
\hline Mississippi River & MS-2 & 163.0 & 68.8 \\
\hline Mississippi River & MS-3 & 375.6 & 160.4 \\
\hline Mississippi River & MS-4 & 697.4 & 544.5 \\
\hline Mississippi River & MS-5 & $1,000.8$ & 841.5 \\
\hline Niobrara River & NI-1 & 278.1 & 154.0 \\
\hline Niobrara River & $\mathrm{NI}-2$ & 263.2 & 89.2 \\
\hline Niobrara River & $\mathrm{NI}-3$ & 178.1 & 67.4 \\
\hline
\end{tabular}


Table 4. Average width of channel masks per river flow segment. Mask widths were quantified by merging all masks from any flow segment/path/row overlaps for each river flow segment. These merged masks were analyzed with Rivwidth (Pavelsky and Smith, 2008) to quantify average mask width and standard deviation of mask width per river flow segment. Data are from Bulliner (2018).-Continued

$[--$, not applicable $]$

\begin{tabular}{lccc}
\hline \multicolumn{1}{c}{ River name } & $\begin{array}{c}\text { Flow } \\
\text { segment }\end{array}$ & $\begin{array}{c}\text { Mean mask } \\
\text { width } \\
\text { (meters) }\end{array}$ & $\begin{array}{c}\text { Mask width } \\
\text { standard deviation } \\
\text { (meters) }\end{array}$ \\
\hline Platte River & PL-1 & 303.6 & 85.0 \\
Platte River & PL-2 & 200.8 & 108.4 \\
Red River & RE-1 & 212.1 & 173.4 \\
Red River & RE-2 & 200.9 & 120.9 \\
Red River & RE-3 & 158.6 & 61.6 \\
Red River & RE-4 & 149.1 & 112.0 \\
Red River & RE-5 & 328.9 & 136.0 \\
Red River & RE-6 & 245.7 & 244.7 \\
Red River & RE-7 & 169.9 & 138.2 \\
Red River & RE-8 & 166.7 & 85.5 \\
Red River & RE-9 & 297.7 & 140.3 \\
Red River & RE-10 & 388.7 & 251.2 \\
Red River & RE-11 & 532.1 & 280.8 \\
Red River & RE-12 & 106.7 & 68.1 \\
Red River & RE-13 & 257.8 & 282.5 \\
Red River & RE-14 & 458.6 & 359.0 \\
-- & Mean & 329.3 & 202.6 \\
\hline
\end{tabular}

\section{National Land Cover Dataset Buffers}

Filtering criteria such as distance from large trees and developed features were created from the National Land Cover Dataset (NLCD) 2011 edition (Jin and others, 2013) and U.S. Forest Service Tree Canopy Dataset, also developed from the 2011 NLCD, to better differentiate sandbars that are appropriate for ILT use compared to those that are not. For each flow segment, masks from all overlapping paths/rows were merged into a single active-channel mask. This mask was buffered by a distance of $4 \mathrm{~km}$ into the flood plain. Within this distance, we identified any features in the NLCD 2011 classified as "Developed" (one of five cover types including the name "Developed") and any pixels with a tree canopy value greater than 20 percent in the tree canopy dataset. These features were grouped, dissolved, and buffered by distances of $71 \mathrm{~m}$ and $142 \mathrm{~m}$. The $142 \mathrm{~m}$ distance was selected because ILTs will rarely nest within $142 \mathrm{~m}$ of trees, buildings, or other large human structures (Upah, 2011; Lott and others, 2013). The $71 \mathrm{~m}$ buffer was meant to be an intermediary value to identify areas of marginal habitat quality. These buffers are included as part of this data series.

\section{Image Classification}

This section describes the classification methods used to identify areas of water, sand, and vegetation within the active-channel masks and describes the products included in this data series. Landsat images trimmed to flow segment/path/ row overlaps and masked to the active channel were classified into land-surface cover types to quantify sandbar area in the imagery. This classification was coarse and was meant only to differentiate inundated area, bare sand, and vegetated bars within the created active-channel masks. This work assumed that these were the only cover types possible within the active channel mask and that these features were spectrally distinct enough to be distinguished easily using theoretical thresholds from band ratios. Furthermore, locating validation datasets for this work was difficult because of the ephemeral nature of sandbars, which vary with time morphodynamically and hydrodynamically. Unless validation data were collected the same day as a Landsat image, it was difficult to discern whether observed differences between the classification and validation data were caused by classification issues or simply because of physical changes in the sandbar, river stage, or both. These data must themselves be classified, potentially introducing bias depending on the classification method used. Because of the scarcity of ground-truth data for calibration, three different classification schemes were developed and included in this data series using different decision-tree rulesets. These schemes differ primarily in their classification of mixed pixels, which are somewhere between 50 and 100 percent of a given cover type, including river features such as recently inundated sand or pixels that are a mixture of open water and sandbar. Precise classification of these pixels without calibration data is challenging. The different rulesets are presented so that future work may focus on better identifying validation datasets and determining which classification scheme is the most accurate. We present a comparison of the classification schemes to two hand-digitized classification datasets based on U.S. Department of Agriculture National Agriculture Imagery Program (NAIP) below in "Classification Results."

Not all rivers included in the initial spatial extent were used to create classification data. Because of project time constraints, creation of classification and cover-type frequency products focused on areas with greater density of ILTs. Additionally, although areas in overlapping paths are useful for analysis because they are imaged several days apart, areas in overlapping rows are less informative because images are collected only several minutes apart. Classification focused only on images from one WRS-2 row per flow segment per date for overlapping areas. The flow segments that were included in the final classification work and the number of analyzed flow segment/path/row intersections used for classification datasets in each flow segment are shown in table 5. 
Table 5. Number of analyzed flow segment/path/row intersections for each classified flow segment. Data are from Bulliner (2018).

\begin{tabular}{|c|c|c|}
\hline River name & $\begin{array}{c}\text { Flow } \\
\text { segment }\end{array}$ & $\begin{array}{c}\text { Number of } \\
\text { classified path/row } \\
\text { intersections }\end{array}$ \\
\hline Arkansas River & AR-1 & 1 \\
\hline Arkansas River & $\mathrm{AR}-2$ & 4 \\
\hline Arkansas River & AR-3 & 4 \\
\hline Arkansas River & $\mathrm{AR}-4$ & 2 \\
\hline Arkansas River & AR-5 & 2 \\
\hline Arkansas River & AR-6 & 3 \\
\hline Canadian River & $\mathrm{CA}-1$ & 2 \\
\hline Canadian River & $\mathrm{CA}-2$ & 3 \\
\hline Canadian River & $\mathrm{CA}-3$ & 3 \\
\hline Canadian River & $\mathrm{CA}-4$ & 3 \\
\hline Cimarron River & $\mathrm{CI}-1$ & 2 \\
\hline Cimarron River & $\mathrm{CI}-2$ & 2 \\
\hline Cimarron River & $\mathrm{CI}-3$ & 3 \\
\hline Missouri River & MO-6 & 3 \\
\hline Missouri River & $\mathrm{MO}-7$ & 1 \\
\hline Missouri River & MO-9 & 2 \\
\hline Missouri River & MO-10 & 3 \\
\hline Mississippi River & MS-1 & 1 \\
\hline Mississippi River & MS-2 & 1 \\
\hline Mississippi River & MS-3 & 2 \\
\hline Mississippi River & MS-4 & 3 \\
\hline Mississippi River & MS-5 & 4 \\
\hline Niobrara River & NI-1 & 2 \\
\hline Niobrara River & NI-2 & 1 \\
\hline Niobrara River & $\mathrm{NI}-3$ & 2 \\
\hline Platte River & PL-1 & 2 \\
\hline Platte River & PL-2 & 2 \\
\hline Red River & RE-1 & 5 \\
\hline Red River & RE-2 & 1 \\
\hline Red River & RE-3 & 1 \\
\hline Red River & RE-4 & 3 \\
\hline Red River & $\mathrm{RE}-5$ & 2 \\
\hline Red River & $\mathrm{RE}-6$ & 4 \\
\hline Red River & RE-7 & 3 \\
\hline Red River & RE-8 & 1 \\
\hline Red River & RE-9 & 2 \\
\hline Red River & $\mathrm{RE}-10$ & 2 \\
\hline Red River & RE-11 & 2 \\
\hline Red River & RE-12 & 1 \\
\hline Red River & $\mathrm{RE}-13$ & 2 \\
\hline Red River & RE-14 & 2 \\
\hline
\end{tabular}

\section{Classification Workflow}

Because of the large spatial scale of this work, it was not feasible to develop individual remote sensing protocols using validation data at a regional to Landsat image level scale. Rather, the goal of this work was to apply standardized, theoretical thresholds to widely used normalized band ratios, which are effective means of discriminating surface features based on their reflectance characteristics. Normalized band ratios and values from individual bands were used along with a decision tree ruleset held constant across the spatial extent of the data series.

After the initial classification from scheme A described below, analysis of the classification data showed several additional images in some flow segment/path/rows that included too much snow, ice, cloud cover, or a combination of the three to create reasonable classification results using the basic classification rulesets presented. Therefore, images were inspected manually a second time using full-resolution preview images generated from the downloaded Landsat imagery. These images were higher resolution than the initial preview images used and allowed for a more accurate assessment of image usability. Images that contained snow, ice, or clouds for an analyzed flow segment were excluded from further analysis. These images also were removed from the initial classification results so that the number of classified images for each flow segment/path/row would remain consistent.

\section{Classification Schemes}

This section describes the three different classification schemes used to characterize land cover within the generated analysis masks. Images were classified using a combination of scripts from the Python ${ }^{\circledR}$ (Python Software Foundation) module arcpy (Esri, Inc.) and IDL $₫$ version 8.2 (Exelis Visual Information Solutions, Boulder, Colorado). Images were classified using rulesets generated from theoretical thresholds presented in Ji and others (2009).

Classification scheme A used the classification ruleset presented in figure 3 . In this ruleset, any pixel with an MNDWI value greater than 0.123 was considered to be water. This value is the theoretical threshold for a pixel with 100 percent water as defined in Ji and others (2009). Next, any pixel with an MNDWI value greater than 0 but less than 0.123 was considered to be mixed water. This threshold was somewhat arbitrary and meant to represent pixels where there was some mixture of water, sand, and vegetation. For remaining pixels, any pixels with an NDVI greater than 0.430 , the theoretical threshold for 12.5 percent vegetation given 75 percent water and 12.5 percent bare soil in a pixel, were considered to be vegetation (Ji and others, 2009); these pixels represent a minimum of 12.5 percent vegetation coverage. We considered any pixels with an NDVI greater than this threshold to have sufficient vegetation to preclude usage as habitat by the ILT and, thus, classified them as vegetation. This group was split into two so that classification results would be somewhat 


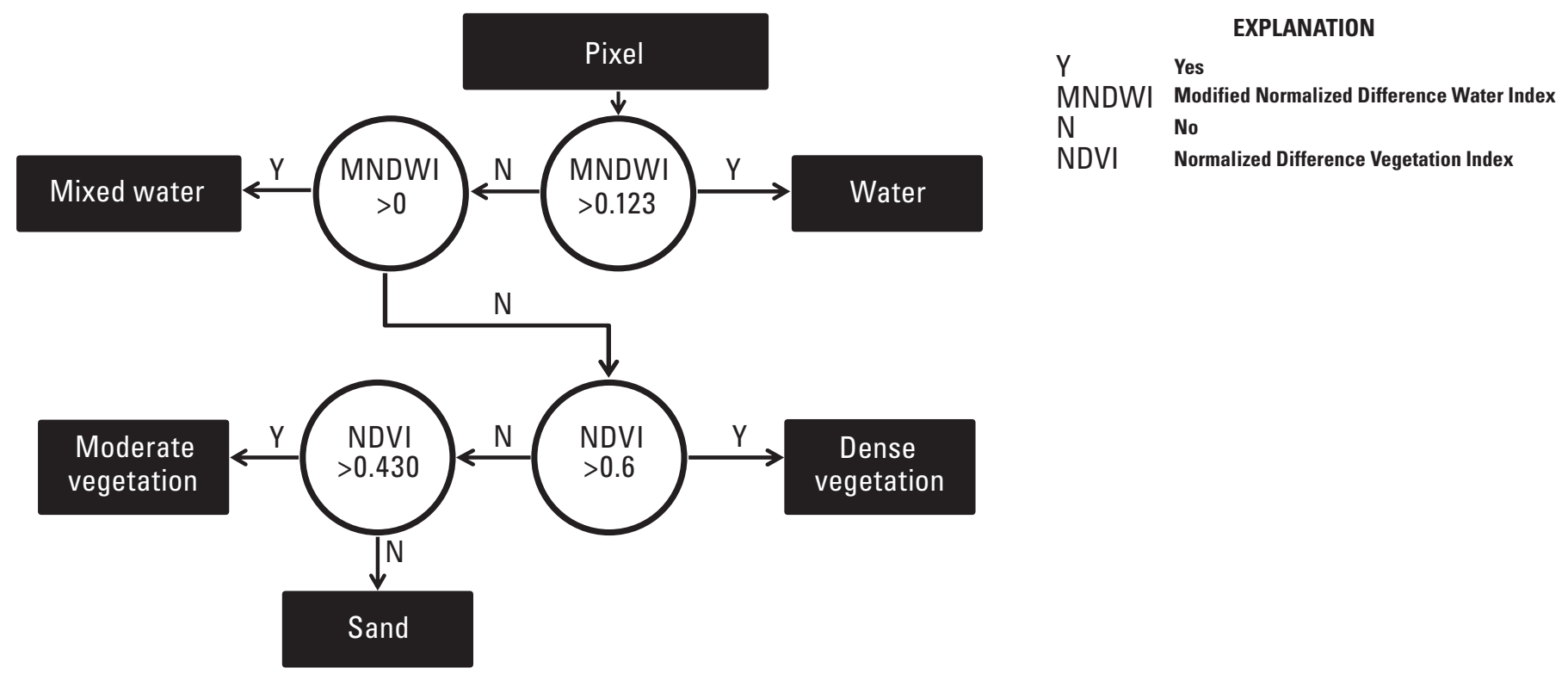

Figure 3. Classification scheme A ruleset.

indicative of vegetation density. These groups included pixels that had an NDVI value greater than 0.6 , an arbitrary threshold, and pixels that had an NDVI value between 0.430 and 0.6. The 0.6 threshold by itself was not chosen to have significant meaning; rather, transitions for a pixel from below to above the threshold (or vice versa) represent increases (or decreases) in vegetation density. These changes within a year or between years may be useful to investigate vegetation dynamics that may alter ILT habitat availability on sandbars.

Classification scheme B used the classification ruleset presented in figure 4 . In this ruleset, the same rules were followed as scheme A. The only difference between schemes A and $\mathrm{B}$ was that the mixed water class spanned MNDWI values from -0.356 (theoretical threshold for 75 percent water and 25 percent sand) to 0.123 instead of 0 to 0.123 ( $\mathrm{Ji}$ and others, 2009). This classification scheme should, therefore, be more conservative in identifying sandbar areas for ILT use.

Classification scheme $\mathrm{C}$ used the classification ruleset presented in figure 5. This ruleset used a somewhat different approach than schemes A and B, the purpose of which was to better characterize pixels that were some mixture of open water and sandbars. In addition to thresholds for 100 percent of a given cover type, Ji and others (2009) present various theoretical NDVI and MNDWI values for pixels with different combinations of sand, water, and vegetation coverage. This classification scheme attempted to separate pixels that were easily identified as 100 percent of a given cover type from those that were a mixture and to create separate cover types for mixed pixels denoting to some extent what kind of mixture existed for that pixel. Output coverage types for this classification scheme included 100 percent sand and water in addition to vegetation (minimum 12.5 percent coverage) pixels as before, but instead of one mixed-water class, there were two classes consisting of 50 percent vegetation/50 percent water and 50 percent sand $/ 50$ percent water. This ruleset started by breaking the MNDWI value for each pixel into one of three classes. Pixels with an MNDWI value above 0.123 were again considered to be 100 percent water; however, in an additional difference from the previous rulesets, these pixels were reclassified as 100 percent sand if the band 7 reflectance was greater than the band 2 reflectance. This additional rule was meant to identify bare sand pixels that had been misclassified as water because the high reflectivity of bright sand can cause increased MNDWI values. High levels of reflectance in the far infrared range (band 7) along with a high MNDWI indicate a pixel is a highly reflective surface feature, such as bright sand, instead of water (Ji and others, 2009). For pixels with an MNDWI between -0.568 and 0.123 , the same band 7 versus band 2 comparison was applied, and pixels with high band 7 reflectance were again classified as 100 percent sand. Pixels meeting this MNDWI criterion but having higher reflectance in band 2 versus band 7 were considered a mixture of sand and water or a mixture of vegetation and water. For these pixels, any with an NDVI greater than 0.527 were considered a mixture of 50 percent vegetation and 50 percent water, whereas those with an NDVI less than 0.527 were considered a mixture of 50 percent sand and 50 percent water. Lastly, for pixels with an MNDWI less than -0.568 , NDVI thresholds were used to determine the class for the pixel. Those with an NDVI value greater than 0.6 were considered 100 percent dense vegetation, those with an NDVI value between 0.430 and 0.6 were considered 100 percent moderate vegetation, and the rest were considered 100 percent sand. The number of images that were processed using all three classification rulesets and met all quality criteria for each flow segment/path/ row combination is shown in table 6 . 


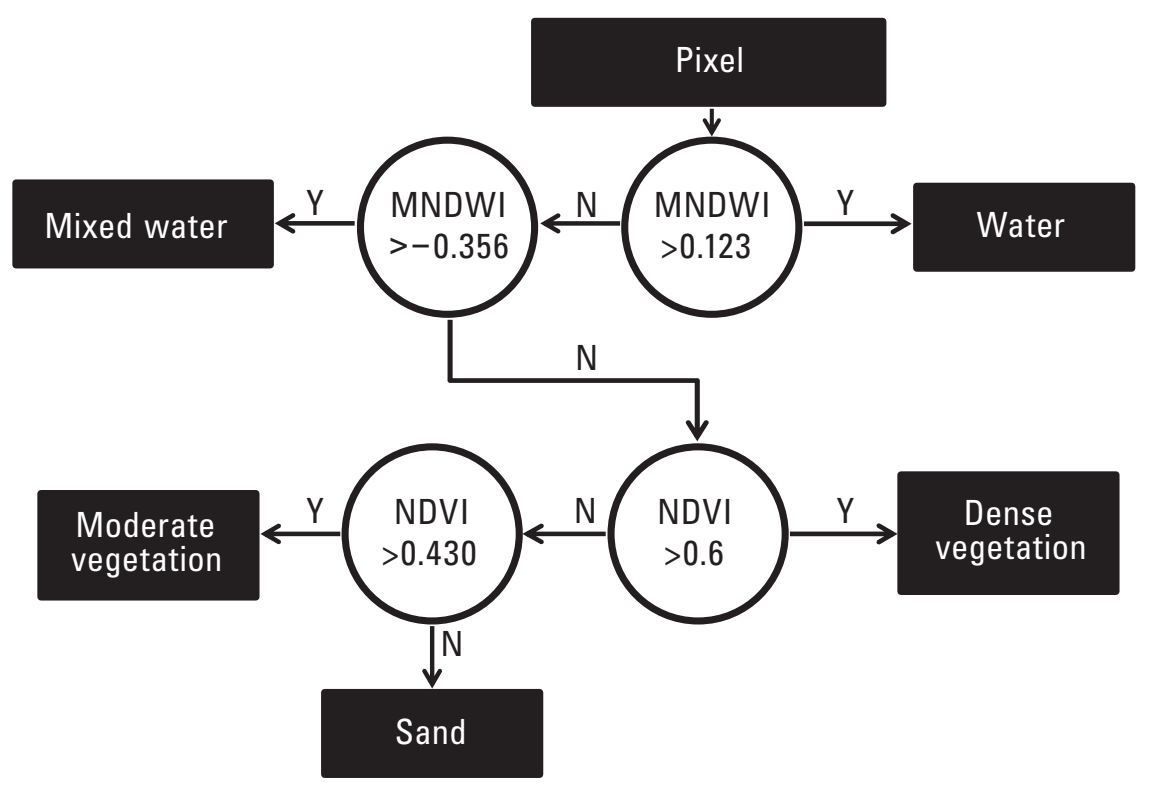

\begin{tabular}{ll} 
& \multicolumn{1}{c}{ EXPLANATION } \\
Y & Yes \\
MNDWI & Modified Normalized Difference Water Index \\
N & No \\
NDVI & Normalized Difference Vegetation Index
\end{tabular}

Figure 4. Classification scheme B ruleset.

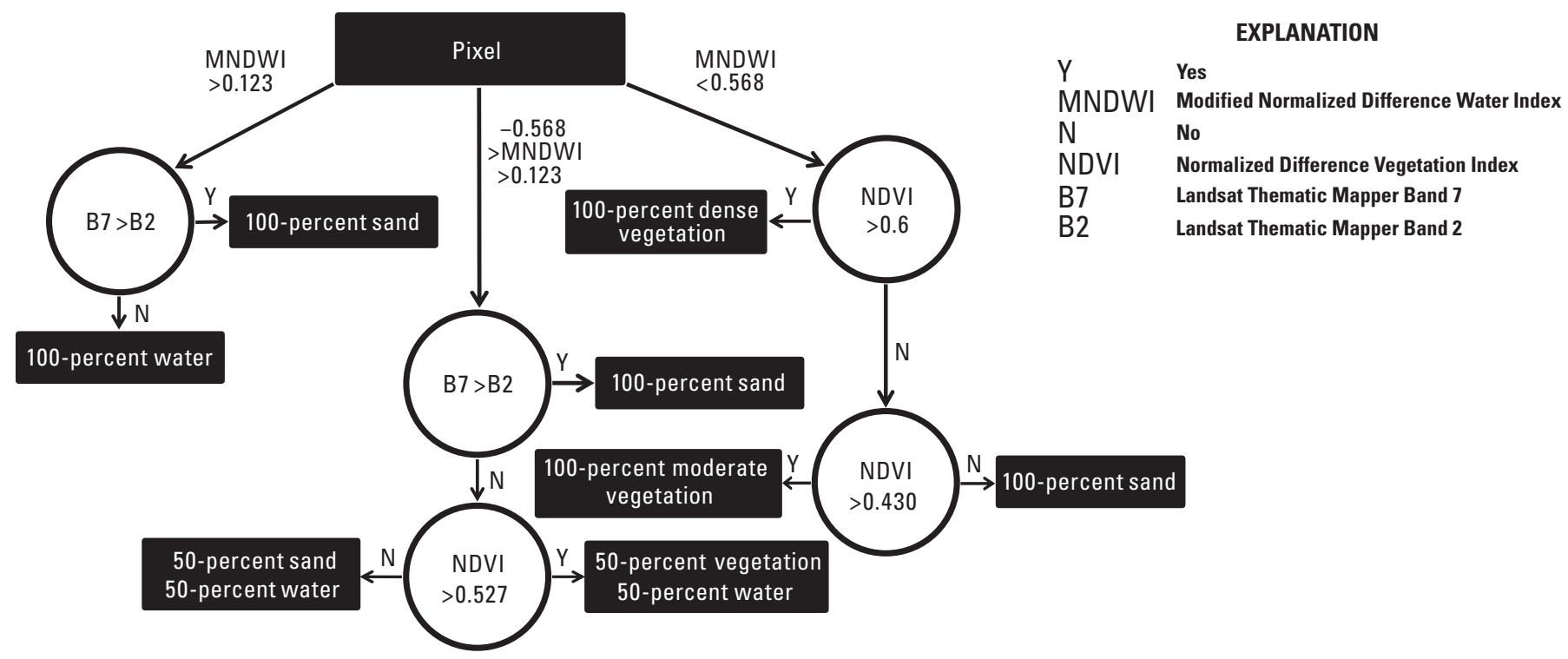

Figure 5. Classification scheme $\mathrm{C}$ ruleset. 
Table 6. Number of images meeting all quality criteria analyzed for each flow segment/path/row combination in which classification results were generated. These images were processed using three different classification rulesets. Data are from Bulliner (2018).

\begin{tabular}{|c|c|c|c|}
\hline Segment/path/row & Number of images classified & Segment/path/row & Number of images classified \\
\hline AR1_23036 & 197 & MS1_23039 & 138 \\
\hline AR2_23036 & 225 & MS2_23038 & 162 \\
\hline AR2_23037 & 194 & MS3_23037 & 164 \\
\hline AR2_24036 & 180 & MS3_23038 & 202 \\
\hline AR2_25036 & 187 & MS4_23035 & 191 \\
\hline AR3_25035 & 205 & MS4_23036 & 158 \\
\hline AR3_25036 & 203 & MS4_23037 & 207 \\
\hline AR3_26035 & 187 & MS5_22034 & 199 \\
\hline AR3_26036 & 222 & MS5_22035 & 181 \\
\hline AR4_26035 & 177 & MS5_23034 & 172 \\
\hline AR4_27035 & 187 & MS5_23035 & 148 \\
\hline AR5_27035 & 203 & NI1_29030 & 162 \\
\hline AR5_28035 & 214 & NI1_30030 & 135 \\
\hline AR6_27035 & 231 & NI2_30030 & 146 \\
\hline AR6_28034 & 227 & NI3_30030 & 151 \\
\hline AR6_28035 & 235 & NI3_31030 & 160 \\
\hline CA1_26035 & 225 & PL1_28031 & 155 \\
\hline CA1_26036 & 216 & PL1_28032 & 160 \\
\hline CA2_26036 & 202 & PL2_28031 & 142 \\
\hline CA2_27035 & 220 & PL2_29031 & 160 \\
\hline CA2_27036 & 196 & RE1_23038 & 117 \\
\hline CA3_27036 & 193 & RE1_23039 & 147 \\
\hline CA3_28035 & 222 & RE1_24038 & 126 \\
\hline CA3_28036 & 231 & RE1_25037 & 156 \\
\hline CA4_28035 & 219 & RE1_25038 & 192 \\
\hline CA4_29035 & 199 & RE2_25037 & 175 \\
\hline CA4_30035 & 278 & RE3_25037 & 183 \\
\hline CI1_27035 & 198 & RE4_25037 & 170 \\
\hline CI1_28035 & 217 & RE4_26036 & 176 \\
\hline CI2_28035 & 187 & RE4_26037 & 182 \\
\hline CI2_29035 & 254 & RE5_26036 & 185 \\
\hline CI3_28035 & 227 & RE5_26037 & 198 \\
\hline CI3_29034 & 260 & RE6_26036 & 197 \\
\hline CI3_29035 & 223 & RE6_26037 & 172 \\
\hline MO6_28030 & 125 & RE6_27036 & 192 \\
\hline MO6_28031 & 129 & RE6_27037 & 200 \\
\hline MO6_29030 & 158 & RE7_27036 & 203 \\
\hline MO7_29030 & 172 & RE7_27037 & 193 \\
\hline MO9_29030 & 174 & RE7_28036 & 236 \\
\hline MO9_30030 & 154 & RE8_28036 & 247 \\
\hline MO10_32027 & 121 & RE9_28036 & 245 \\
\hline MO10_32028 & 129 & RE9_29036 & 240 \\
\hline MO10_33027 & 143 & RE10_28036 & 241 \\
\hline
\end{tabular}


Table 6. Number of images meeting all quality criteria analyzed for each flow segment/path/row combination in which classification results were generated. These images were processed using three different classification rulesets. Data are from Bulliner (2018). - Continued

\begin{tabular}{lc}
\hline Segment/path/row & Number of images classified \\
\hline RE10_29036 & 240 \\
RE11_28036 & 269 \\
RE11_29036 & 231 \\
RE12_29036 & 235 \\
RE13_29036 & 214 \\
RE13_30036 & 263 \\
RE14_29036 & 256 \\
RE14_30036 & 246 \\
Sum & 18,166 \\
\hline
\end{tabular}

Classified images were saved as geotiff files in the same local UTM projection as the original Landsat images. Byte values for each image correspond to different land cover classes. This convention was kept the same for schemes A and $\mathrm{B}$, but a new system was created for scheme C. For summary purposes, such as the cover-type frequency work described below, each cover type was summarized as a sand, vegetation, or water pixel. The cover type corresponding to each byte value in classified images and associated summary cover type is described in table 7. Note that schemes A and B skip from 3 to 5; this skip is a relic of an older classification system used before the final versions presented in this data series.

\section{Classification Results}

We did not complete an exhaustive validation of the classification on a per river or per flow segment basis because of the variable availability of potential sources for validation data. Rather, we present a sensitivity analysis comparing the classification outputs from the three classification schemes on a per flow segment/path/row overlap basis to evaluate the differences in classified land cover. Furthermore, we present a comparison to a pair of hand-digitized NAIP images to demonstrate classification performance relative to humandetermined ground-truth data.

A sensitivity analysis comparing the three classification schemes is presented in table 8. For this analysis, we summarized each flow segment/path/row overlap by the summation of pixels classified as sand, vegetation, or water across all analyzed images. Classified values are summarized according to the "Summary Type" column for each classification scheme listed in table 7; for example, "Water" and "Mixed Water" are counted as "Water" for the sensitivity analysis. Values as a ratio relative to classification scheme $\mathrm{A}$ are presented in
Table 7. Classification legend for classification schemes A, B, and $\mathrm{C}$.

[A summary type of "--" refers to no data; mask cells are not summarized as any of the types]

\begin{tabular}{|c|c|c|}
\hline $\begin{array}{c}\text { Byte } \\
\text { value }\end{array}$ & Cover description & $\begin{array}{c}\text { Summary } \\
\text { type }\end{array}$ \\
\hline \multicolumn{3}{|c|}{ Scheme A } \\
\hline 0 & Mask & -- \\
\hline 1 & Water & Water \\
\hline 2 & Mixed water & Water \\
\hline 3 & Moderate vegetation & Vegetation \\
\hline 5 & Dense vegetation & Vegetation \\
\hline 6 & Sand & Sand \\
\hline \multicolumn{3}{|c|}{ Scheme B } \\
\hline 0 & Mask & -- \\
\hline 1 & Water & Water \\
\hline 2 & Mixed Water & Water \\
\hline 3 & Moderate vegetation & Vegetation \\
\hline 5 & Dense vegetation & Vegetation \\
\hline 6 & Sand & Sand \\
\hline \multicolumn{3}{|c|}{ Scheme C } \\
\hline 0 & Mask & -- \\
\hline 1 & 100 percent water & Water \\
\hline 2 & 50 percent vegetation $/ 50$ percent water & Water \\
\hline 3 & 50 percent sand $/ 50$ percent water & Water \\
\hline 4 & 100 percent sand & Sand \\
\hline 5 & Moderate vegetation & Vegetation \\
\hline 6 & Dense vegetation & Vegetation \\
\hline
\end{tabular}

table 8; a value of 0.5 means that half as many pixels were classified as a given cover type relative to scheme A.

In general, scheme A identified the largest amount of bare sand. As anticipated, introducing a wider range of MNDWI values considered water in the first step of the decision tree caused more pixels to be identified as water in classification scheme B. This difference is most marked on upper flow segments of southern plains rivers, such as the Red, Canadian, and Cimarron Rivers, which included as much as 40 times as many pixels classified as water relative to scheme A, mostly because of scheme A detecting little water in most images because of small channel widths and expansive open point bars of these systems during seasonal low flows. The largest differences in classification schemes in terms of methodology were between schemes $\mathrm{A}$ and $\mathrm{B}$ relative to scheme $\mathrm{C}$ with the introduction of mixed pixels. Even when counting these pixels as water, scheme $\mathrm{C}$ identified fewer pixels as water relative to scheme B and was closer overall to scheme A in water identified and sand identified. Scheme A identified more pixels as vegetation and sand relative to schemes B and C. Differences 


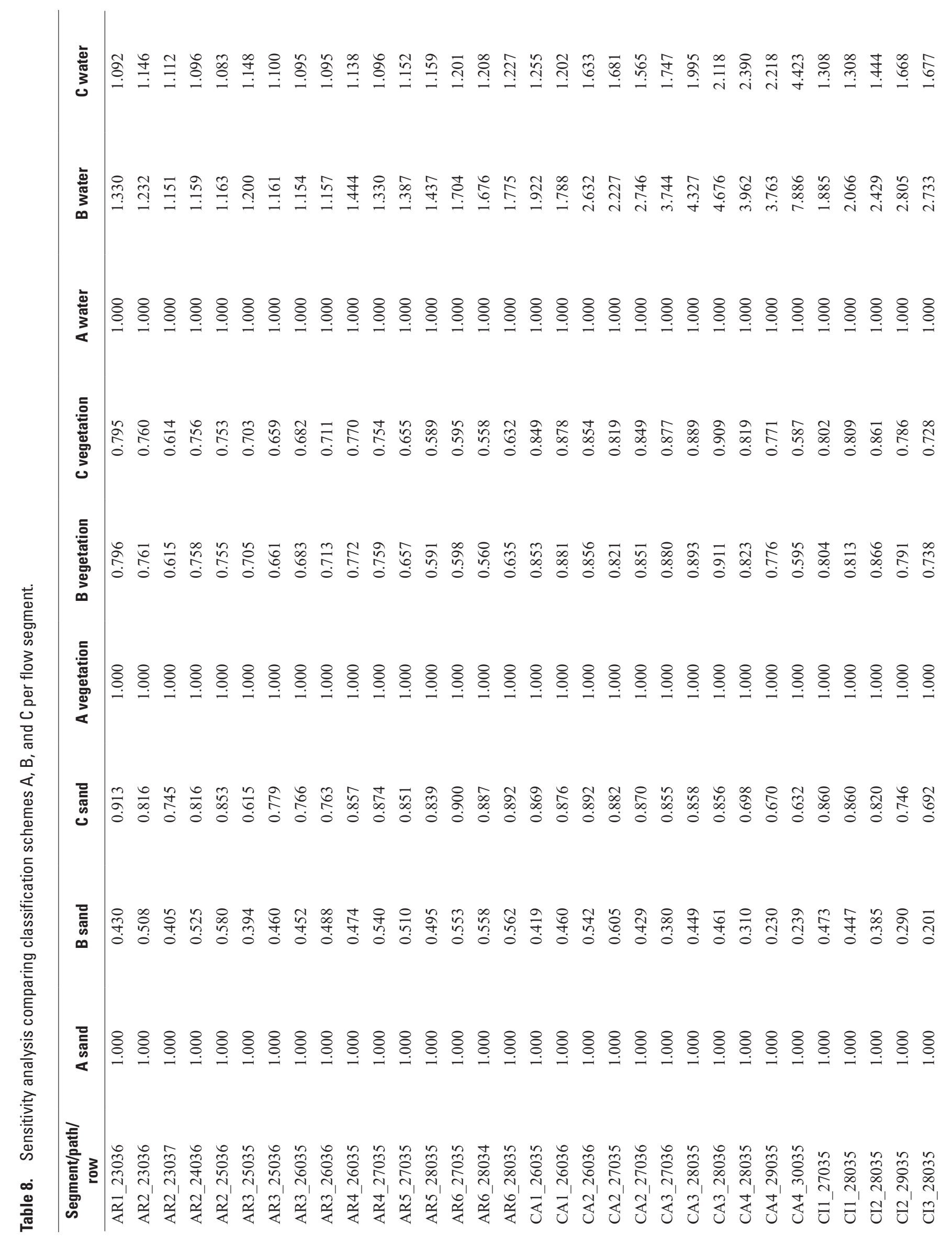




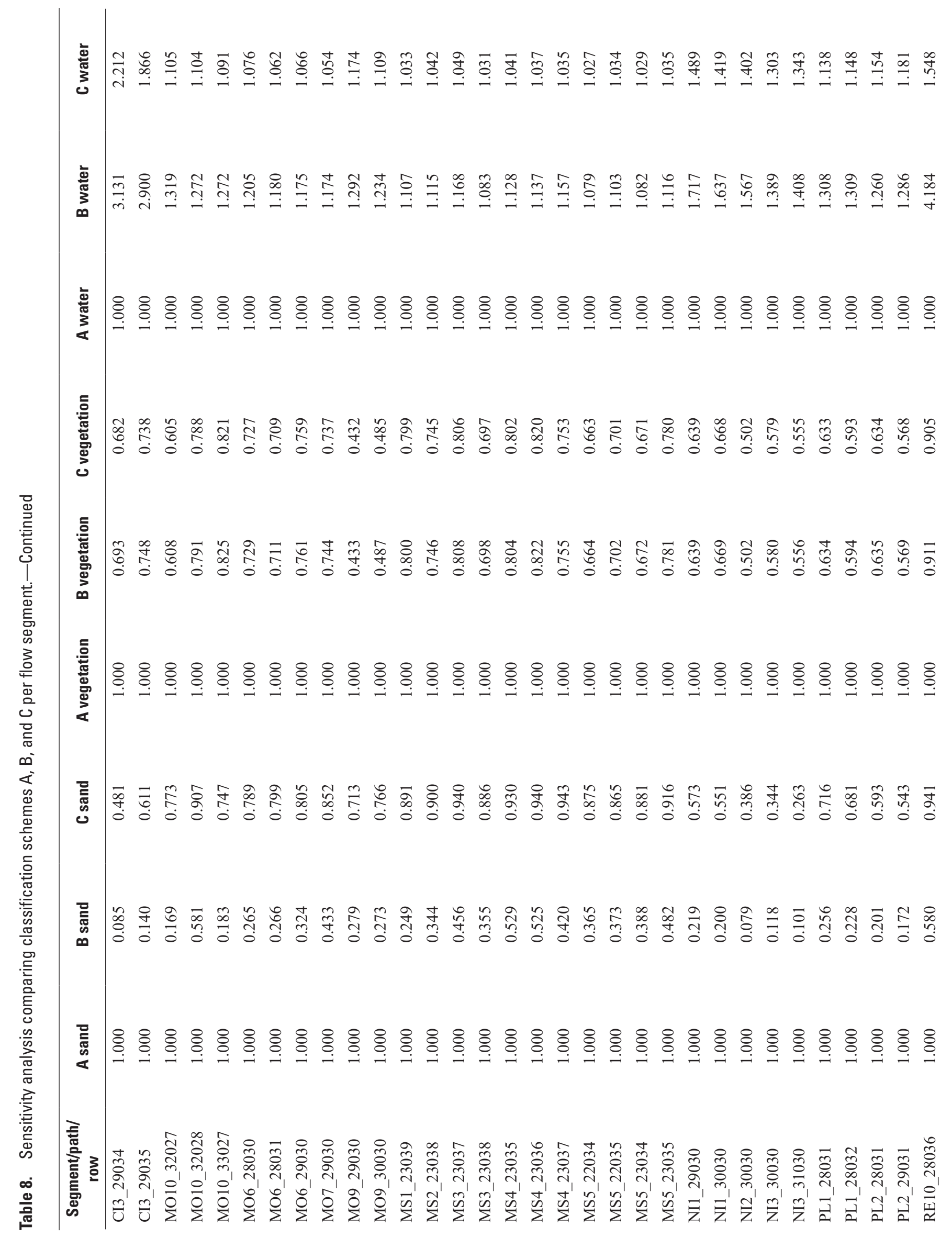




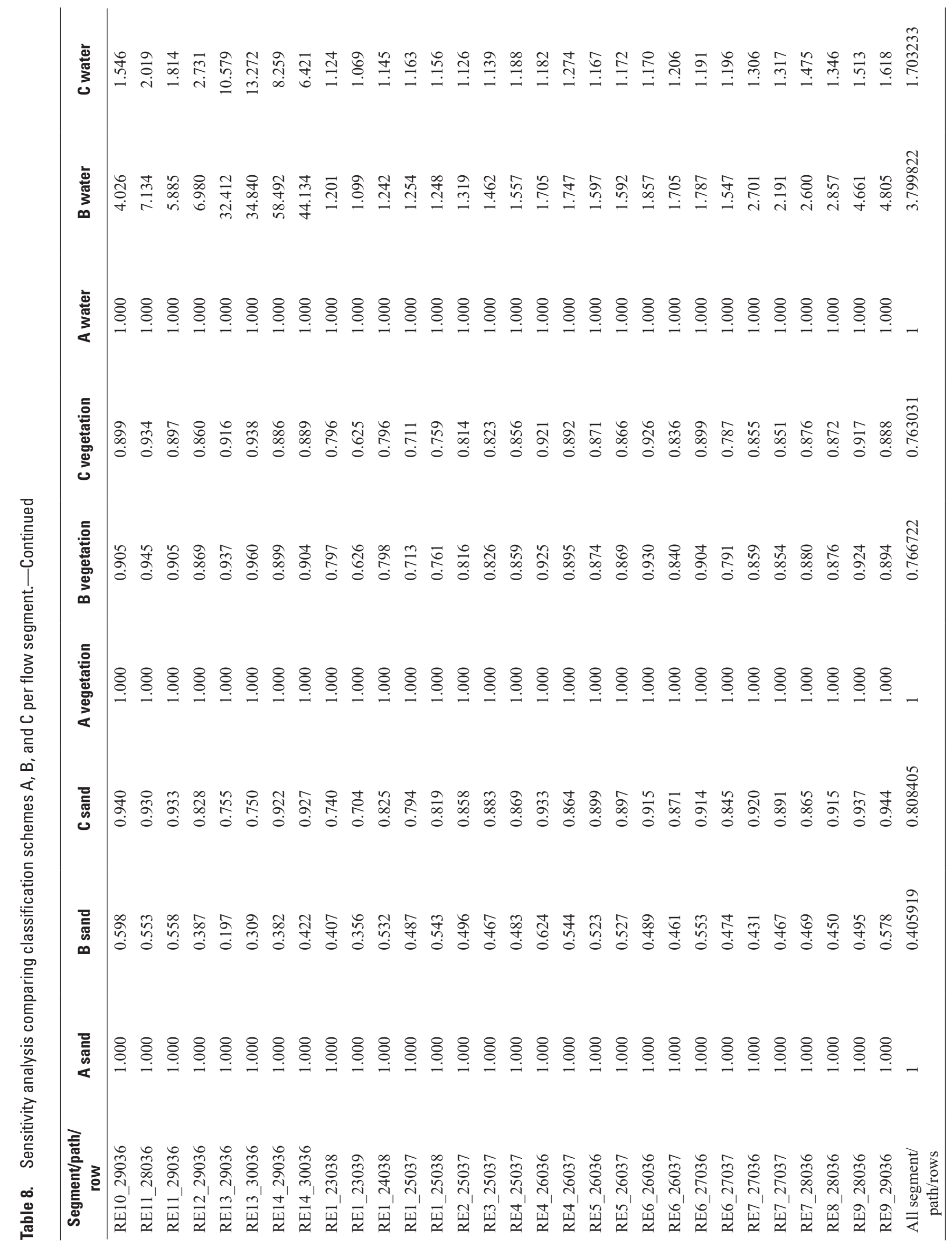


in classified pixels between schemes often happen along the edges of bars and shore, and in areas with patchy vegetation, showing the sensitivity of pixels with a mixture of cover types to changes in normalized band-ratio thresholds. An example of this difference is shown in figure 6, which compares classification schemes for one Landsat image on the Red River, flow segment 4.

Because the dates a given location is imaged through the NAIP program are irregular, unlike the Landsat program, and these dates are, to the authors' knowledge, not readily available in a database format that would allow an automated search similar to our approach for Landsat imagery outlined in this report, we chose to identify a priori 2 river locations, 1 from a northern river (Missouri River flow segment 6) and 1 from a southern river (Red River flow segment 5) with a mixture of sand, vegetation of differing density, and water that would allow for a full test of classification performance. We then used USGS EarthExplorer (https://earthexplorer.usgs. gov) (U.S. Geological Survey, 2018) to identify available NAIP images for these locations. For an NAIP image to be used for comparison to our classified data, we decided that the image should be within 16 days of an analyzed Landsat image from an overlapping flow segment/path/row combination to ensure similar vegetation state and bar morphology (generally resulting in 2 possible Landsat images to use per NAIP image given that Landsat has a 16 day return period, 1 before and 1 after, unless the Landsat image was collected on the same day as the NAIP image). Because the Landsat 4-5 dataset we generated only extends through 2011, we, therefore, did not consider any NAIP images from 2012 or later. For our two selected locations, we used EarthExplorer to examine the dates for available NAIP images pre-2012. Out of the available NAIP images, we selected an image where the analyzed Landsat image within 16 days criterion was met. Furthermore, we established that flow percentile given the discharge record within the Landsat record period for the overlapping flow segment should be within 15 percent as compared to the corresponding Landsat image. Because we did not expect to find images at exactly matching discharges, we established this broad discharge criterion to ensure we were comparing NAIP and Landsat images within similar discharge "ranges;" that is, comparing only images that were from the same qualitative category such as low or moderate discharge. This discharge range creates the caveat that differences in classified Landsat images and the hand-digitized NAIP data result not only from differences in classification but potentially from slight differences in inundated area as well.

For the Red River, we chose an area along flow segment 5 corresponding to quarter-USGS quadrangle (the address system for NAIP imagery) 3309506 southeast. This area overlapped with flow segment/path/row RE5_26037. For this location, there were four NAIP images available within EarthExplorer that were collected in or before 2011. The NAIP image that best matched the discharge of a contemporaneous Landsat image was collected on August 27, 2010, corresponding to Landsat image LT50260372010228PAC01 collected on
August 16, 2010. The daily average discharges attributed to flow segment Red 5 for the two images were $5,144 \mathrm{ft}^{3} / \mathrm{s}$ for the NAIP image and 5,252 $\mathrm{ft}^{3} / \mathrm{s}$ for the Landsat image. These discharges corresponded to flow percentiles of 45.4 percent and 46.0 percent, respectively, given discharge records during the Landsat 4-5 record period.

For the Missouri River, we chose an area along flow segment 6 corresponding to quarter-USGS quadrangle 4209617 northwest. This area overlapped with flow segment/path/ row MO6_29030. For this location, there were six images available within EarthExplorer that were collected in or before 2011. Several of these images had matching Landsat images within an acceptable discharge range. We opted not to select the closest image in terms of discharge relative to a contemporaneous Landsat image because it was at a higher discharge with less sand and vegetation available to test classification accuracy. We selected an NAIP image collected on July 22, 2008, that corresponded to Landsat image LT50290302008196PAC01 collected on July 14, 2008. The daily average discharges attributed to flow segment Missouri-6 for the two images were 19,312 $\mathrm{ft}^{3} / \mathrm{s}$ for the NAIP image and $14,427 \mathrm{ft}^{3} / \mathrm{s}$ for the Landsat image. These discharges correspond to flow percentiles of 29.7 percent and 17.3 percent, respectively, given discharge records during the Landsat 4-5 record period.

For each NAIP image, we hand-digitized areas within the active-channel mask used for our Landsat analysis. Each image was categorized into water, dark sand (generally sand that appeared to be recently inundated), light sand, moderate vegetation (generally sparsely vegetated bars and open areas with vegetation), and dense vegetation (generally well-established tree stands). We digitized imagery at a 1:6,000 scale. After digitizing the images, we converted them into rasters with the same $30-\mathrm{m}$ scale spatial resolution snapped to Landsat imagery to allow for direct pixel-to-pixel comparisons. We used a majority resampling tool to translate each 30-m pixel into a value corresponding to the digitized features that covered the greatest areal extent within that pixel. Raw NAIP images, hand-digitized classification data, and Landsat-based automated classification for schemes A, B, and C are shown for the Red River image in figure 7 and the Missouri River image in figure 8.

Classifications from our three Landsat-based classification schemes generally agreed with the hand-digitized coverages generated from NAIP imagery. We present specific comparisons in the form of individual confusion matrices per classification scheme and cover type in table 9 (available for download at https://doi.org/ds1098) for the Red River NAIP image and table 10 (available for download at https://doi.org/ ds1098) for the Missouri River NAIP image. For the purposes of this analysis, we summarized cover types as sand, vegetation, and water for each classification dataset and used these summaries to calculate producer accuracy, user accuracy, and overall accuracy (Story and Congalton, 1986). We summarized Landsat classification schemes according to table 7, and NAIP classification data as moderate and dense vegetation summing 

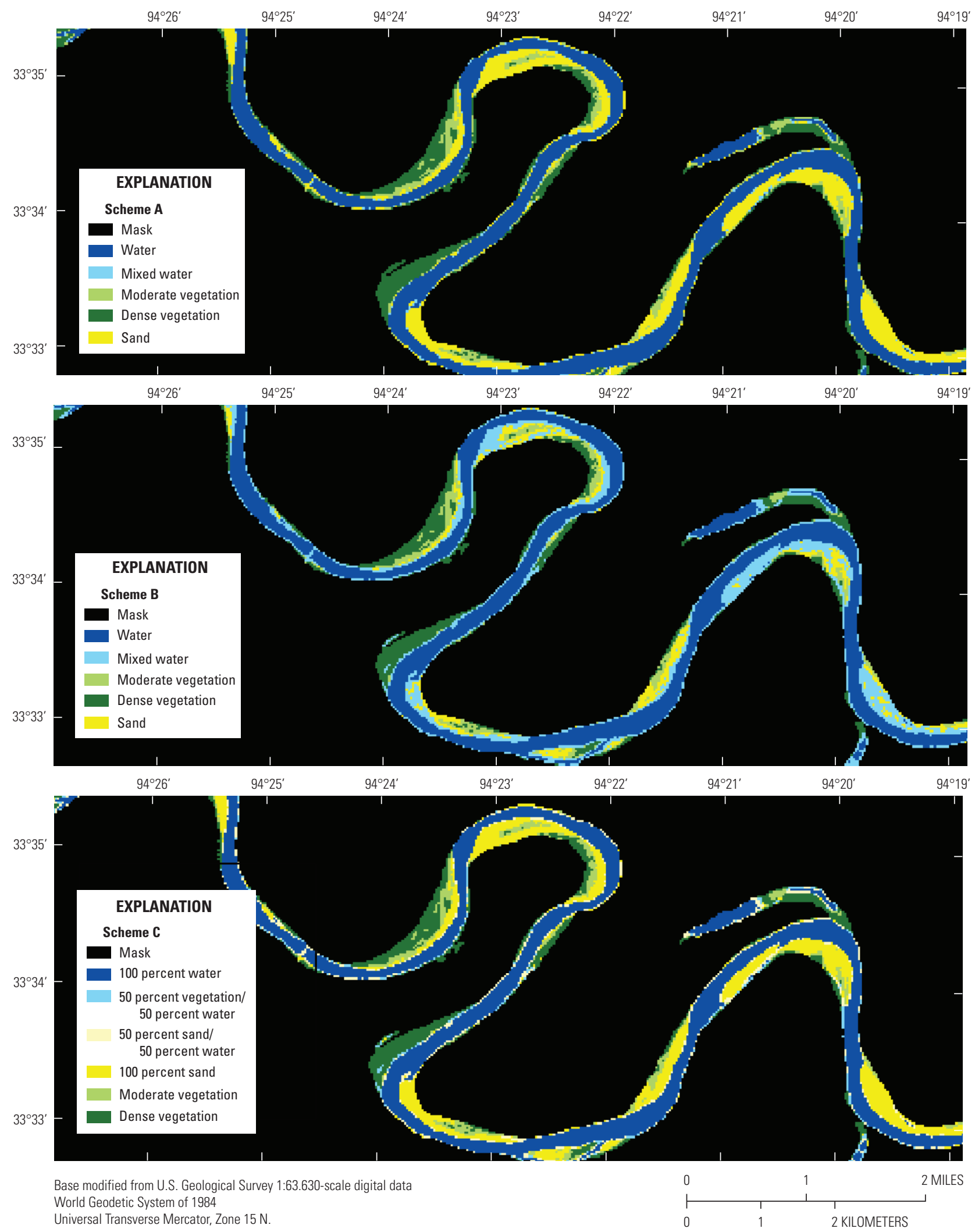

Figure 6. A sample of classification data for flow segment Red 4, path/row 25037. The maps compare classification schemes A, B, and C for Landsat image LT50250372004125PAC02. Data are from Bulliner (2018). 

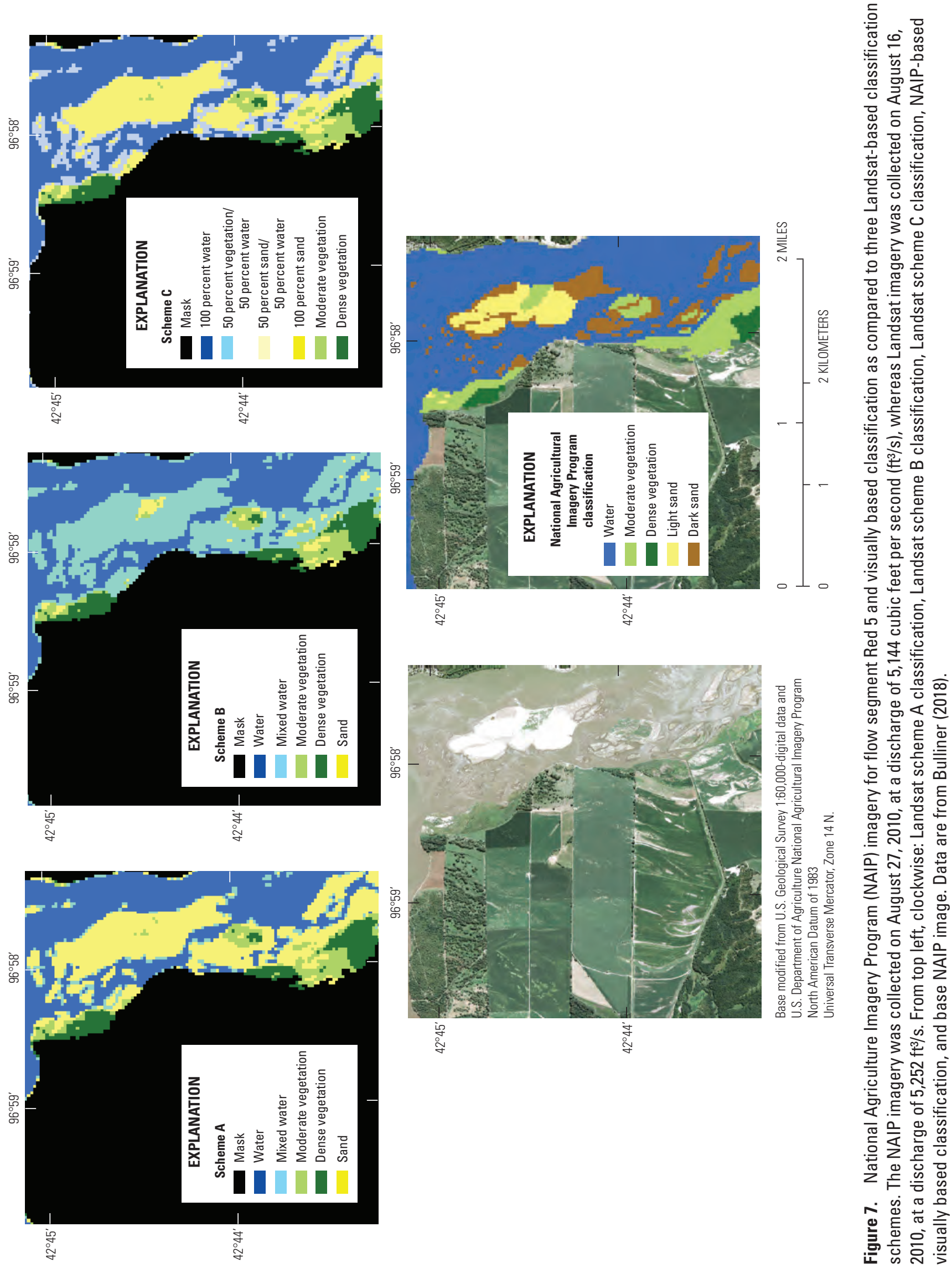

更

ฐ

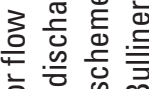

흥 क

离䒕管

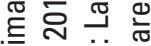

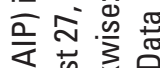

范焉口

就은

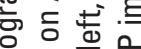

웡응

ब.

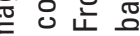

ब范

를 중.

离范范

응 히에

흔 준 흥

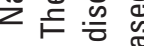

ن

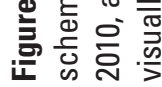



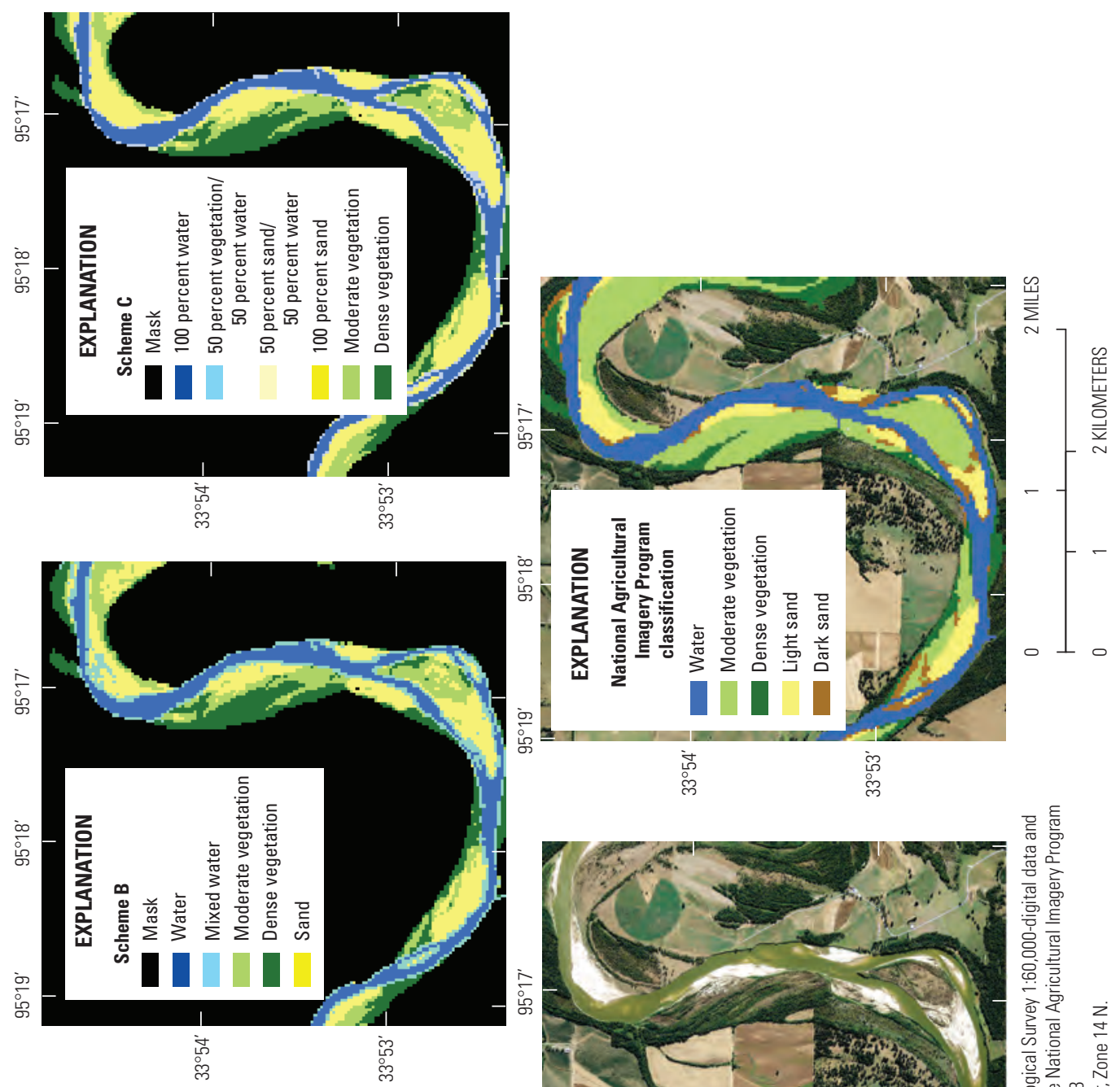

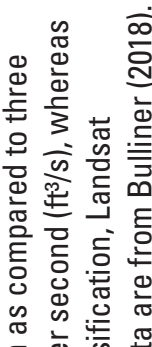

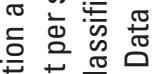

듕

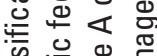

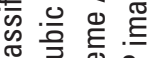

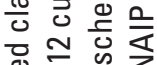

噁

呵

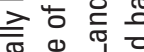

苛

类需

든

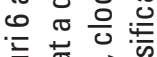

荡舟

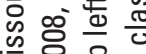

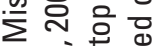

처ํ

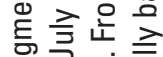

के

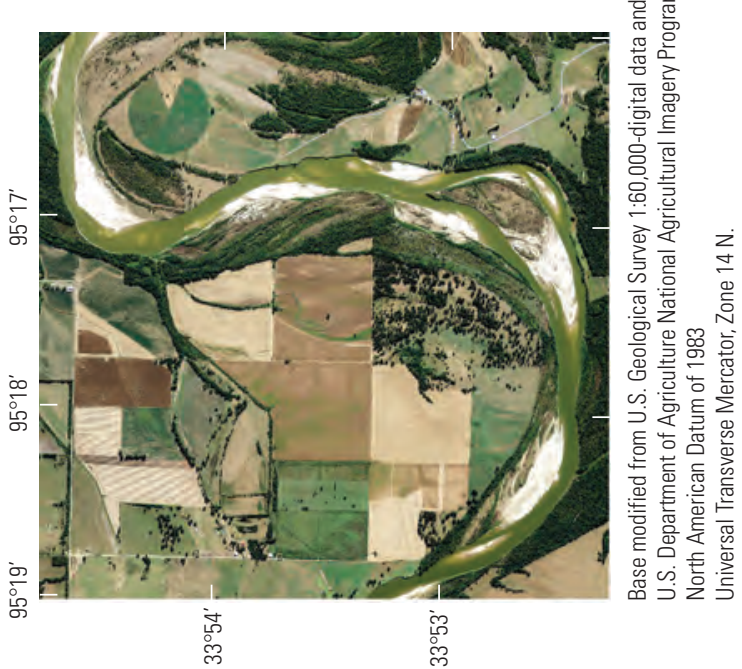

3응

운

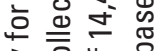

궁

离

.

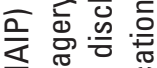

¿.

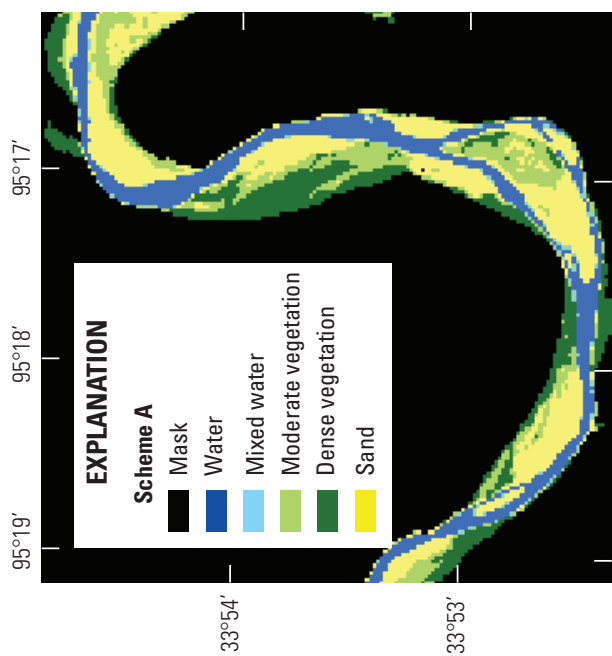

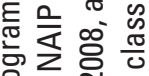

잉 品过。

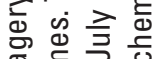

Е

넝응

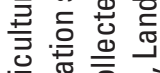

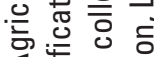

这震

등 $\frac{\pi}{0} \geq$.

융웧엉

$z$ 电

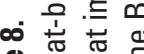

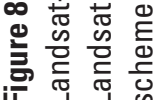


as vegetation, light and dark sand summing as sand, and water summing as water. Note that the NAIP classification scheme equates to Landsat classification schemes A and B in terms of cover classes but with sand split out into light sand versus dark sand in the NAIP scheme. In addition to the summarized confusion matrices, we present direct comparisons between lower-level cover classes where applicable (such as dense vegetation in NAIP imagery versus dense vegetation in classification scheme A) and exploratory comparisons between values summarized as one cover type in the Landsat classification schemes, but possibly matching better with another cover type in the NAIP classification scheme. For example, we compare 50 percent sand/50 percent water pixels from classification scheme $\mathrm{C}$ with dark sand in the NAIP imagery to determine if these pixels would be better summarized as sand. These comparisons are presented in table 11 (available for download at https://doi.org/ds1098) for the Red River and table 12 (available for download at https://doi.org/ds1098) for the Missouri River.

For summary purposes, NAIP-based classifications are presented as "truth" for determining user accuracy, producer accuracy, and overall accuracy for our Landsat classifications. However, because NAIP-based classifications were subjective based on visual interpretation of imagery, and also are based on images at slightly different times and discharges relative to the Landsat images, NAIP classifications are only an approximation of ground-truth data. Producer accuracy was defined as the number of pixels classified as the same cover type in a Landsat and NAIP image divided by the sum of all pixels classified as that cover type in the NAIP image. User accuracy was defined as the number of pixels classified as the same cover type in a Landsat and NAIP image divided by the sum of all pixels classified as that cover type in the Landsat image. Overall accuracy was defined as the sum of all pixels classified as the same cover type in both images divided by the total number of classified pixels in one image.

For the Red River NAIP image, scheme $\mathrm{C}$ had the best overall accuracy, at 84.5 percent versus 84.0 percent for scheme B and 80.9 percent for scheme A. In terms of utility for mapping changes in sandbar habitat, producer and user accuracies for sand may be more relevant. Scheme A had the greatest producer accuracy for sand (88.4 percent), or the largest proportion of pixels classified as sand in the Landsat image relative to all pixels classified as sand in the NAIP image. In this context, larger values of producer accuracy mean more pixels in the NAIP image classified as sand are captured by the Landsat classification. All three classification schemes had low user accuracies; scheme B had the greatest user accuracy of these at 55.9 percent; however, this scheme also was associated with the lowest producer accuracy at 64.8 percent. In this context, a higher user accuracy means that more pixels classified as sand in the Landsat image are actually sand (assuming the NAIP image as ground truth). A higher producer accuracy than user accuracy corresponds to more pixels being classified as sand in the Landsat classification scheme relative to the NAIP image. The low user accuracy for sand across all three classes generally resulted from pixels identified as vegetation in NAIP imagery being identified as sand in the Landsat classification schemes. This misclassification likely is because of the subjective identification of vegetated areas in digitizing the NAIP imagery; it is likely that such pixels correspond to areas of sparse vegetation without a high enough NDVI to appear as vegetation in Landsat classification schemes. Because small amounts of vegetation are known to preclude the usage of sandbars by ILTs for nesting, further investigation into specific NDVI thresholds that would preclude sand pixels from use by ILTs for nesting is warranted before using the classification schemes presented to inventory habitat. However, for purposes of geomorphic change analysis, one of the goals of this work, misclassifications between sand and vegetation are more acceptable; of more interest is morphodynamic and hydrodynamic change between water and sand/vegetation (nonwater).

For the Missouri River, scheme $\mathrm{C}$ also had the highest overall accuracy at 90.8 percent. Scheme A again had the highest user accuracy at 98.4 percent, scheme $\mathrm{C}$ instead of $\mathrm{B}$ had the highest user accuracy at 63.9 percent (while still maintaining a high producer accuracy of 93.1 percent). A notable outlier for this image was scheme B, which had a very low producer accuracy for sand of 5.7 percent and a low user accuracy of 25.1 percent. In this set of images, most pixels classified as sand in the NAIP image were classified as water in scheme B. For the Missouri River, the low user accuracy for sand in scheme A was mostly because of pixels classified as water in the NAIP image being classified as sand in the Landsat image. For scheme $\mathrm{C}$, the lower user accuracy was because of a mix of misclassifying vegetation and water pixels. Because the Landsat image was at a lower discharge than the NAIP image (by a margin greater than the Red River comparison), some of the pixels classified as sand in the Landsat image but water in the NAIP image may be associated with areas of emergent sand as river stage dropped; user accuracies for sand may therefore be higher for this comparison in reality relative to what is reported.

Comparisons of individual cover type classes are shown in tables 11 and 12 . We wished to quantify if some of the misclassifications between sand and water were a result of damp areas of sand being identified as water. We also wished to evaluate how our arbitrary NDVI thresholds for moderate versus dense vegetation compared to visual delineations of moderate versus dense vegetation in NAIP imagery. For the Red River, 98.5 percent of pixels classified as light sand in NAIP imagery also were classified as sand by classification scheme A. In contrast, only 63.5 percent of pixels classified as dark sand in NAIP imagery were classified as sand by classification scheme A, indicating most areas missed by Landsat scheme A for classifying sand were in wet areas for this classification scheme. This pattern was similar for schemes B and C for the Red River but was not apparent on the Missouri River images, indicating regional differences in classification performance. Pixels classified as 50 percent sand/50 percent water in classification scheme $\mathrm{C}$ do not seem to indicate areas of dark sand identified in NAIP images; only 10.6 percent of pixels 
classified as this value correspond to NAIP pixels classified as dark sand for the Red River image and 9.5 percent for the Missouri River image. Areas of moderate and dense vegetation generally agreed between Landsat classification schemes and NAIP images, and the largest discrepancies were pixels classified as moderate vegetation in NAIP images (NAIP-true) but not in Landsat images (NAIP-false), again corresponding to the sparsely vegetated areas classified as vegetation in NAIP imagery described above.

\section{Cover Type Frequency}

Landsat imagery is georeferenced such that each pixel represents (about) the same ground location across all images; therefore, it is possible to stack classified images together to make calculations for comparative or summary purposes. The classification data were used to count the number of times each pixel within the active channel masks was classified as bare sand, vegetation, or open water. These analyses were used to create what are hereafter referred to as "sand addition," "vegetation addition," and "water addition" files, and indicate areas of persistent sand and inundation, respectively, across the Landsat TM record period.

Classification data were summarized into cover type frequency files using IDL version 8.2 (Exelis Visual Information Solutions, Boulder, Colorado). The IDL script reads images as two-dimensional matrices in single-band imagery such as a land-cover classification map, and matrix coordinates match the image coordinates (Exelis Visual Information Solutions, 2010). For sand addition and water addition files, individual land-cover classification maps were converted to binary rasters with values of 1 where the feature of interest was identified and values of 0 elsewhere. The result of adding matrices generated from these together for each analyzed image in a flow segment/ path/row is a single matrix that counts the number of times each pixel coordinate was classified as the feature of interest. This matrix was saved as a geotiff file that can be added to maps. A second version of these addition files that normalized the number of times a pixel was counted as a cover type by the total number of images analyzed also was created; values presented are in percent of total images.

Only images meeting a minimum discharge threshold were used to create these files. Because ILTs are known to use high elevation sand (Lott and Wiley, 2012), the sand-addition files were adjusted to omit lower elevation sand not usable by ILTs during their nesting season. The numeric criterion for this minimum discharge threshold was the 5 th percentile of daily flow values during the nesting season (defined as May 25-July 12 for this purpose), except in flow segments with hydropower peaking (daily or subdaily power-production flow releases). For these flow segments, the daily average hydropower peak was used as the minimum discharge threshold with the assumption that any sand below this threshold would be inundated on a daily basis. Minimum discharge thresholds used for the creation of sand and water addition files are presented in table 13 .
Total-image versions and normalized-percentage versions for sand, vegetation, and water cover type frequency files are presented for each classification scheme as part of this data series. Additionally, each version is presented in the date-limited version, only considering images between days of year 116 and 296, which is the average time of foliation for the continental United States (Jeong and others, 2011). These datelimited versions do not include areas that are bare soil during the wintertime but become vegetated during the summer as part of their count and may be better suited to identifying areas of ILT use. Images and discharges were programmatically filtered using the pandas module in Python to create lists of images to use for various sand and water addition files (McKinney, 2012). A sample of cover type addition files is provided in figure 9, which shows normalized-percentage date-limited sand, vegetation, and water addition files for Red River flow segment 4, path/row 25037.

\section{Product Descriptions}

The following products are available as part of this data series. These products were developed primarily from Landsat CDR surface reflectance data, which is available from https://earthexplorer.usgs.gov and hosted by USGS EROS. All derived data are available on the USGS ScienceBase website in a data release (Bulliner, 2018). Specific data formats and directory structures are described in the following sections.

\section{Database}

The database includes all compiled discharge records and Landsat metadata for TM images within the data series spatial extent. It also includes tools to list Landsat images meeting user-specified date, geolocation (flow segment or WRS-2 path/row), and discharge criteria. The version of the database associated with this report is V. 3.0.

\section{Database Forms}

The primary intended means to interact with this database is through two forms, "Imagery" and "Discharge." The "Imagery" form opens by default and includes instructions for its use as part of the form. The purpose of the "Imagery" form is to list Landsat images for particular rivers. These images can be sorted by either date or discharge, and filters can be applied to either criterion. Lists of images meeting these criteria can be created for exporting as text files to be used with the USGS EarthExplorer bulk data downloading service (https://earthexplorer.usgs.gov). The "Discharge" form lists discharge or stage values, depending on which is available for a given flow segment. These values can be filtered by date. 
Table 13. Minimum discharge thresholds used to create sand and water addition files. Data are from Bulliner (2018).

$\left[\mathrm{ft}^{3} / \mathrm{s}\right.$, cubic foot per second]

\begin{tabular}{|c|c|c|c|c|c|}
\hline Flow segment & Minimum discharge/stage & Unit & Flow segment & Minimum discharge/stage & Unit \\
\hline AR-1 & $3,992.80$ & $\mathrm{ft}^{3} / \mathrm{s}$ & NI-1 & 925.40 & $\mathrm{ft}^{3} / \mathrm{s}$ \\
\hline $\mathrm{AR}-2$ & $3,444.15$ & $\mathrm{ft}^{3} / \mathrm{s}$ & $\mathrm{NI}-2$ & 667.00 & $\mathrm{ft}^{3} / \mathrm{s}$ \\
\hline AR-3 & $4,170.10$ & $\mathrm{ft}^{3} / \mathrm{s}$ & $\mathrm{NI}-3$ & 633.00 & $\mathrm{ft}^{3} / \mathrm{s}$ \\
\hline $\mathrm{AR}-4$ & $1,010.00$ & $\mathrm{ft} 3 / \mathrm{s}$ & PL -1 & $2,078.50$ & $\mathrm{ft}^{3} / \mathrm{s}$ \\
\hline AR-5 & $5,500.00$ & $\mathrm{ft}^{3} / \mathrm{s}$ & PL -2 & $1,254.00$ & $\mathrm{ft}^{3} / \mathrm{s}$ \\
\hline AR-6 & $5,500.00$ & $\mathrm{ft}^{3} / \mathrm{s}$ & RE-1 & 5.70 & $\mathrm{ft}^{3} / \mathrm{s}$ \\
\hline $\mathrm{CA}-1$ & $13,000.00$ & $\mathrm{ft}^{3} / \mathrm{s}$ & RE-2 & $4,000.00$ & $\mathrm{ft}^{3} / \mathrm{s}$ \\
\hline $\mathrm{CA}-2$ & 58.85 & $\mathrm{ft}^{3} / \mathrm{s}$ & RE-3 & $4,000.00$ & $\mathrm{ft}^{3} / \mathrm{s}$ \\
\hline $\mathrm{CA}-3$ & 47.00 & $\mathrm{ft}^{3} / \mathrm{s}$ & RE-4 & $4,000.00$ & $\mathrm{ft}^{3} / \mathrm{s}$ \\
\hline $\mathrm{CA}-4$ & 7.00 & $\mathrm{ft}^{3} / \mathrm{s}$ & $\mathrm{RE}-5$ & $6,000.00$ & $\mathrm{ft}^{3} / \mathrm{s}$ \\
\hline $\mathrm{CI}-1$ & 156.70 & $\mathrm{ft}^{3} / \mathrm{s}$ & RE-6 & $11,000.00$ & $\mathrm{ft}^{3} / \mathrm{s}$ \\
\hline $\mathrm{CI}-2$ & 64.70 & $\mathrm{ft}^{3} / \mathrm{s}$ & RE-7 & 317.55 & $\mathrm{ft}^{3} / \mathrm{s}$ \\
\hline $\mathrm{CI}-3$ & 1.00 & $\mathrm{ft}^{3} / \mathrm{s}$ & RE-8 & 317.55 & $\mathrm{ft}^{3} / \mathrm{s}$ \\
\hline MO-6 & $17,440.00$ & $\mathrm{ft}^{3} / \mathrm{s}$ & RE-9 & 55.85 & $\mathrm{ft}^{3} / \mathrm{s}$ \\
\hline MO-7 & $14,000.00$ & $\mathrm{ft}^{3} / \mathrm{s}$ & $\mathrm{RE}-10$ & 23.00 & $\mathrm{ft}^{3} / \mathrm{s}$ \\
\hline MO-9 & $8,485.00$ & $\mathrm{ft}^{3} / \mathrm{s}$ & RE-11 & 22.85 & $\mathrm{ft}^{3} / \mathrm{s}$ \\
\hline MO-10 & $14,000.00$ & $\mathrm{ft}^{3} / \mathrm{s}$ & $\mathrm{RE}-12$ & 8.00 & $\mathrm{ft}^{3} / \mathrm{s}$ \\
\hline MS-1 & 17.00 & Feet & $\mathrm{RE}-13$ & 0.00 & $\mathrm{ft}^{3} / \mathrm{s}$ \\
\hline MS-2 & 17.23 & Feet & RE-14 & 0.00 & $\mathrm{ft}^{3} / \mathrm{s}$ \\
\hline MS-3 & 18.10 & Feet & & & \\
\hline MS-4 & 7.50 & Feet & & & \\
\hline MS-5 & 10.26 & Feet & & & \\
\hline
\end{tabular}

\section{Database Tables}

The database consists of several tables that contain the underlying Landsat metadata and USGS/USACE streamgage data. Each included table is described in the following list. Most field names for each table are self-explanatory; however, when not immediately clear, the meaning of individual fields is identified here.

- Gage_Assign.-This table contains the streamgages used for discharge data for each flow segment and serves as a link between the "Segments" and "Gages" tables. The primary key, "GageID," is representative of the streamgage number, for USGS streamgages, or a shorthand identification of the USACE data source for all but three flow segments. For the segments RE-14, RE-10, and MS-1, the "GageID" in this table does not match the actual streamgage used for these segments; values for these streamgages were altered in the streamgages table because of a relic of how the database was structured (each flow segment was required to have a unique GageID value). Some

streamgages do not have a flow segment assigned; these represent individual component streamgages used to synthesize streamgage data for flow segments without a representative streamgage.

- Gages.-This table contains discharge or stage values for all flow segments and the individual component streamgages.

- Image_Usability.-This table contains all unique combinations of flow segments and Landsat images. Specific fields include

- Usable.-This field shows if this combination was determined to be cloud free initially.

- LandsatMetadata.-This table contains metadata for all available Landsat imagery within the spatial domain of this project.

- Rivers.-This table is used by the database forms for listing rivers in the spatial domain of this project. 

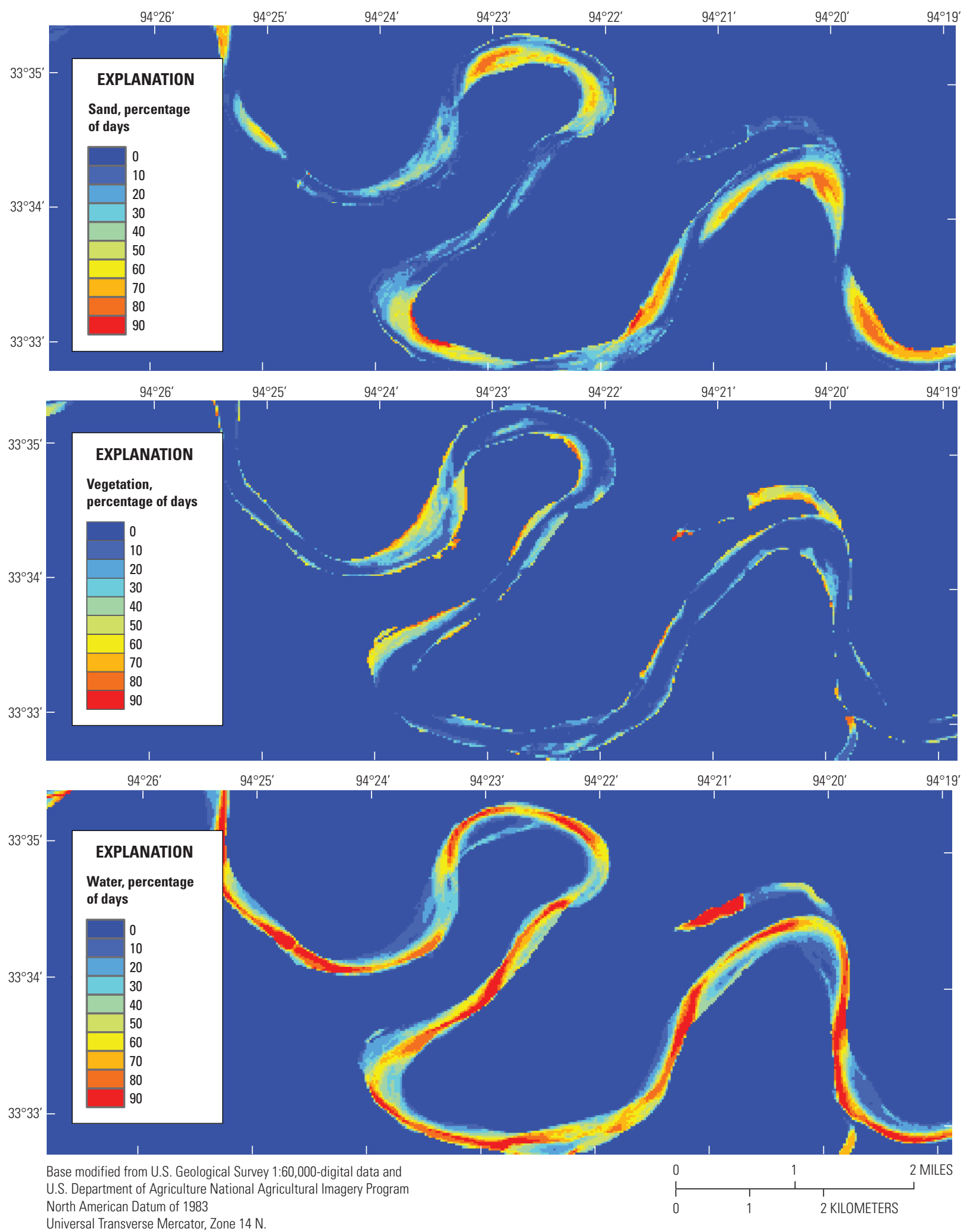

Figure 9. Sample cover type addition files for the Red River flow segment 4, path/row 25037. Pixel values represent the percentage of times a pixel was classified as a given cover type across all analyzed images between days of year 116 and 296, representing an average period for foliation across the central United States. From top to bottom, images represent sand, vegetation, and water. Data are from Bulliner (2018). 
- Segments.-This table links the "Segments_Intersect" and "Gage_Assign" tables.

- Segments_Intersect.-This table lists all possible intersections between flow segments and Landsat WRSPR (Worldwide Reference System path/row) cells.

- WRSPaths.-This table serves to link the "LandsatMetadata" and "Segments_Intersect" tables.

\section{Database Queries}

The database contains numerous queries written for various data summary purposes. Not all queries are currently used in the database forms but have been retained because they are useful for interacting with the data. For database users without experience with Microsoft ${ }^{\circledR}$ Access, it is easier to interact with this database exclusively through the previously described forms. Brief descriptions of each query are included in the following list.

- Base Select Query.-Lists all images for a given flow segment/path/row.

- Base Select Query_Datesort._-Lists all images for a given flow segment/path/row by date; date criteria (if any) are applied.

- Base Select Query-StageSort.-Lists all images for a given flow segment/path/row by stage (for flow segments with stage instead of discharge).

- Base Select Query-StageSortUOnly.-Lists images for a given flow segment/path/row that have been marked as usable (no obscuring clouds in preview) for stage flow segments.

- Base Select Query-Uonly.-Lists images for a given flow segment/path/row that have been marked as usable (no obscuring clouds in preview).

- Bulk Landsat Scene List for Export. - Lists all Landsat scenes marked as usable.

- Discharge Select.-Lists discharge by criteria from form "Discharges."

- LandsatSelect.-Lists all Landsat images within spatial domain of project with Level 1 processing available.

- Landsat Scene List for Export.-Lists Landsat images meeting criteria specified in "Imagery" table in format for easy export as text file.

- Mark Usability.-Lists images meeting criteria in "Imagery" with preview link for quick assessment of cloud-free usability.

- Stage Select.-Lists stage values set by criteria in form "Discharges."
- Static Scene Discharge by Segment. Lists discharges for individual combinations of image and flow segment.

- Static Scene Stage by Segment.-Lists stages for individual combinations of image and flow segment.

\section{Flow Segments and Channel Masks}

Shapefiles that include all flow segments and channel masks identified and created are included with this data series. The directory "RiverSegments" contains one shapefile that shows all flow segments. Flow segment polylines are identified by having only a two-letter river code and number, such as "MO10." The directory "ChannelMasks" contains all flow segment/path/row masks and has one mask per shapefile. Flow segment/path/row masks are identified by a combination of a river code and flow segment number along with a five-digit path/row number, separated by an underscore. A flow segment/path/row mask sample name is "MO6_29030" (Missouri River, segment 6, path/row 29030). Full river names for a given river code are listed in table 1.

\section{National Land Cover Dataset Buffer Files}

Buffers created from tree and developed features are presented on a per flow segment basis. These buffers are trimmed to a distance of $4 \mathrm{~km}$ from combined active channel masks for all path/rows from each flow segment. These buffers are presented in an ArcGIS file geodatabase, and individual flow segments are identified by their name. Two versions of the buffer are presented. One buffer is $71 \mathrm{~m}$ from the identified features, whereas the other is $142 \mathrm{~m}$ from the identified features. These buffer distances are indicated following the flow segment identifier; for example, "MO6_71m" (Missouri River, flow segment $6,71 \mathrm{~m}$ buffer) represents a buffered distance of $71 \mathrm{~m}$ from tree cover and developed features.

\section{Classified Images}

Images classified using all three classification schemes are included with this data series, structured in different directories first by classification scheme and then by flow segment/path/row overlap. Classified images within these directories retain their original Landsat scene identifiers, which contain the date the image was collected. Landsat image names are structured as LXSPPPRRRYYYYDDDGSIVV, where $\mathrm{L}=$ Landsat, $\mathrm{X}=$ sensor, $\mathrm{S}=$ satellite, $\mathrm{PPP}=\mathrm{WRS}$ path, RRR=WRS row, YYYY=year, DDD=Julian day of year, $\mathrm{GSI}=$ ground station identifier, and $\mathrm{VV}=$ archive version number. These images are geotiffs, and byte values represent the cover classes described in Table 7. Images are projected to the original WGS 1984 UTM zone of the corresponding Landsat image. 


\section{Cover Type Addition Files}

For each of the three classification schemes, sand addition, vegetation addition, and water addition files are presented along with classified images in the same directory structure. As in the classified images, presented files are clipped to the path/row/flow segment analysis unit. Raster values represent either the total number of analyzed images or the percentage of analyzed images where the given pixel was classified as the feature of interest (sand, water, or vegetation) depending on the file. Additionally, separate versions exist for files limited to growing season dates of Julian day 116-296 versus files including all dates. Each classification scheme/flow segment/ path/row subdirectory will therefore have 12 sand, vegetation, or water addition files named with the flow segment/path/row overlap followed by an underscore and one of the following suffixes:

- sand-Absolute number of sand images, no date limit.

- sand_d.-Absolute number of sand images, date limited.

- sand_n.-Normalized percentage of sand images, no date limit.

- sand_nd.-Normalized percentage of sand images, date limited.

- water-Absolute number of water images, no date limit.

- water_d.-Absolute number of water images, date limited.

- water_n.-Normalized percentage of water images, no date limit.

- water_nd.-Normalized percentage of water images, date limited.

- veg.-Absolute number of vegetation images, no date limit.

- veg_d.-Absolute number of vegetation images, date limited.

- veg_n.-Normalized percentage of vegetation images, no date limit.

- veg_nd.-Normalized percentage of vegetation images, date limited.

Like the classified images, sand and water cover type frequency files are presented in geotiff format, projected to the same WGS 1984 UTM projection as the original Landsat imagery.

\section{Summary}

In summary, sandbars of large sand-bedded rivers of the central United States serve important ecological functions in the life history of the endangered Interior Least Tern (Sternula antillarum, ILT). These colonial birds nest on riverine sandbars during their annual breeding season of around May through July and feed on fish from nearby river areas. During their nesting period, ILTs require unvegetated sand of sufficient elevation so as not to be inundated between nest initiation and fledging of hatchlings. Decreases in available sandbar habitat from river channelization and impoundment were cited as reasons for the original listing of the ILT by the U.S. Fish and Wildlife Service as endangered.

River hydrology is the primary driver of sandbar dynamics, and sandbars in rivers used by ILTs in the central United States are highly dynamic and undergo substantive changes across a wide range of temporal and spatial scales. Understanding the landscape-scale ecology for sandbar-dependent species such as the ILT requires understanding how changes in flow regime relate to sandbar area with time. This work used remote sensing techniques to quantify sandbar area and relate it to river hydrology to help increase our understanding of how sandbar habitat for the ILT varies with time and space. The analysis is likely relevant to other aquatic and terrestrial species occupying these rivers. The assessment of landscapescale trends in sandbar area requires combining datasets with high temporal resolution and long record periods covering large geographic areas with measurements of river discharge or stage. Land-cover classification datasets within active channel masks were developed using all available images from the Landsat Thematic Mapper series of satellites meeting cloud-free and ice-free criteria. Landsat imagery is well suited to monitoring ILT sandbar habitat with time because of its long record period, spatial coverage, and regular reimaging cycle. Datasets were attributed with river flow records using a developed database integrating U.S. Geological Survey and U.S. Army Corps of Engineers discharge or stage records with Landsat metadata. This report documents the development of three riverine classification datasets with a focus and applicability to ILT nesting habitat on large regulated central United States rivers. This framework may be used in the future to continue a historically consistent monitoring of ILT sandbar nesting habitat or applied to other species and communities that use sandbars on these rivers.

\section{References Cited}

Alexander, J.S., Schultze, D.M., and Zelt, R.B., 2013, Emergent sandbar dynamics in the Lower Platte River in eastern Nebraska-Methods and results of pilot study, 2011: U.S. Geological Survey Scientific Investigations Report 20135031, 42 p. with appendixes. 
Bulliner, E.A., 2018, Interior least tern sandbar nesting habitat measurements from Landsat TM imagery: U.S. Geological Survey data release, https://doi.org/10.5066/F7CV4GNG.

Dixon, M.D., Turner, M.G., and Jin, C., 2002, Riparian tree seedling distribution on Wisconsin river sandbars - Controls at different spatial scales: Ecological Monographs, v. 72, no. 4, p. 465-485.

Engel, J.M., 1985, Endangered and threatened wildlife and plants; interior population of the least tern determined to be endangered: Twin Cities, Minn., U.S. Fish and Wildlife Service, Federal Register, v. 50, no. 102, p. 21784-21792.

Exelis Visual Information Solutions, 2010, IDL reference guide: Boulder, Colo., Exelis Visual Information Solutions, $6010 \mathrm{p}$.

Irish, R.R., 2000, Landsat 7 science data users handbook: National Aeronautics and Space Administration report no. 430-15-01-003-0, $186 \mathrm{p}$.

Jacobson, R.B., 2013, Riverine habitat dynamics: Treatise on Geomorphology, v. 12, p. 6-19.

Jeong, S.J., Ho, C.H., Gim, H.J., and Brown, M.E., 2011, Phenology shifts at start vs. end of growing season in temperate vegetation over the Northern Hemisphere for the period 1982-2008: Global Change Biology, v. 17, no. 7, p. 2385-2399.

Ji, L., Zhang, L., and Wylie, B., 2009, Analysis of dynamic thresholds for the Normalized Difference Water Index: Photogrammetric Engineering and Remote Sensing, v. 75, no. 11, p. 1307-1317.

Jin, S., Yang, L., Danielson, P., Homer, C., Fry, J., and Xian, G., 2013, A comprehensive change detection method for updating the National Land Cover Database to circa 2011: Remote Sensing of Environment, v. 132, p. 159-175.

Johnson, B.L., and Jennings, C.A., 1998, Habitat associations of small fishes around islands in the upper Mississippi River: North American Journal of Fisheries, v. 18, no. 2, p. 327-336.

Lott, C.A., 2006, Distribution and abundance of the interior population of the least tern (Sternula antillarum): U.S. Army Corps of Engineers, Engineer Research and Development Center Environmental Laboratory, Technical Report 06-13, $99 \mathrm{p}$.

Lott, C.A., and Wiley, R.L., 2012, Effects of dam operations on least tern nesting habitat and reproductive success below Keystone Dam on the Arkansas River: U.S. Army Corps of Engineers, Engineer Research and Development Center Environmental Laboratory, Technical Report 12-4, 111 p.
Lott, C.A., Wiley, R.L., Fischer, R.A., Hartfield, P.D., and Scott, J.M., 2013, Interior least tern (Sternula antillarum) breeding distribution and ecology-Implications for population-level studies and the evaluation of alternative management strategies on large, regulated rivers: Ecology and Evolution, v. 3, no. 10, p. 3613-3627.

McKay, L., Bondelid, T., Dewald, T., Johnston, J., Moore, R., and Rea, A., 2012, NHDPlus version 2-User guide: U.S. Environmental Protection Agency, 173 p.

McKinney, W., 2012, Python for data analysis: Sebastopol, Calif., O’Reilly Media, Inc., 451 p.

Pavelsky, T.M., and Smith, L.C., 2008. RivWidth—A software tool for the calculation of river widths from remotely sensed imagery: IEEE Geoscience and Remote Sensing Letters, v. 5, no. 1, p. 70-73.

Rouse, J.W., Haas, R.H., Schell, J.A., and Deering, D.W., 1973, Monitoring vegetation systems in the Great Plains with ERTS - 3d ERTS Symposium: Washington D.C., December 10-14, 1973, NASA SP-351, p. 309-317.

Rubin, D.M., Schmidt, J.C., and Moore, J.N., 1990, Origin, structure, and evolution of a reattachment bar, Colorado River, Grand Canyon, Arizona: Journal of Sedimentary Petrology, v. 60, no. 6, p. 982-991.

Story, M., and Congalton, R.G., 1986, Accuracy assessmentA user's perspective: Photogrammetric Engineering and Remote Sensing, v. 53, no. 3, p. 397-399.

Thompson, B.C., Jackson, J.A., Burger, J., Hill, L.A., Kirsch, E.M., and Atwood, J.L., 1997, Least tern-Sterna antillarum, in Poole, A., and Gill, F., eds., Birds of North America: Washington D.C., The Academy of Natural Sciences, Philadelphia, Pennsylvania, and the American Ornithologists' Union, p. 1-32.

Upah, C., 2011, The final programmatic environmental impact statement on the mechanical/artificial creation of emergent sandbar habitat (ESH) on the riverine reaches of the upper Missouri River: U.S. Army Corps of Engineers, Omaha District, Federal Register 29217, v. 76, no. 98, p. 29217-29218.

U.S. Fish and Wildlife Service, 1990, Recovery plan for the interior population of the least tern (Sterna antillarum): Twin Cities, Minn., U.S. Fish and Wildlife Service, 90 p.

U.S. Fish and Wildlife Service, 2005, Biological opinion addressing sixteen federally listed threatened or endangered species on the Arkansas, Canadian, and Red RiversArkansas, Oklahoma, and Texas; and on the McClellan-Kerr Arkansas Navigation System: Tulsa, Okla., U.S. Fish and Wildlife Service, $157 \mathrm{p}$.

U.S. Fish and Wildlife Service, 2013, Interior least tern, 5-year review—Summary and evaluation: Jackson, Miss., U.S. Fish and Wildlife Service, Southeast Region, 75 p. 
U.S. Geological Survey, 2013a, Landsat missions: U.S. Geological Survey web page, accessed January 8, 2013, at https://landsat.usgs.gov/metadatalist.php.

U.S. Geological Survey, 2013b, National Hydrography Dataset-The national map download viewer: U.S. Geological Survey web page, accessed October 2013 at https://viewer. nationalmap.gov/basic/?basemap $=$ b1\&category $=$ nhd\&title $=$ NHD\%20View.

U.S. Geological Survey, 2014a, Eros science processing architecture (ESPA) ordering interface: U.S. Geological Survey web page, accessed January 16, 2014, at https://espa.cr.usgs. gov/.

U.S. Geological Survey, 2014b, Landsat Surface Reflectance Climate Data Records: U.S. Geological Survey Fact Sheet 2013-3117, 1 p. [Also available at https://doi.org/10.3133/ fs20133117.]
U.S. Geological Survey, 2016, USGS water data for the Nation: U.S. Geological Survey National Water Information System database, accessed June 2017 at https://doi. org/10.5066/F7P55KJN.

U.S. Geological Survey, 2018, EarthExplorer: U.S. Geological Survey web page, accessed September 2018 at https://earthexplorer.usgs.gov/.

Xu, H., 2006, Modification of normalised difference water index (NDWI) to enhance open water features in remotely sensed imagery: International Journal of Remote Sensing, v. 27 , no. 14 , p. 3025-3033.

For more information about this publication, contact:

Director, USGS Columbia Environmental Research Center

4200 New Haven Road

Columbia, M0 65201

573-875-5399

For additional information, visit: https://www.usgs.gov/centers/cerc

Publishing support provided by the

Rolla Publishing Service Center 



\section{$\frac{\mathbb{2}}{3}$}

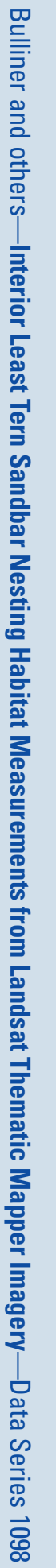

